\title{
THE EVOLUTION OF ABSORPTIVE CAPACITY IN THE SCIENTIFIC LITERATURE: A BIBLIOMETRIC ANALYSIS FOCUSED ON INNOVATION
}

\author{
(iD) Tainá Alves Townsend ${ }^{1}$ (D) Cristiane Drebes Pedron ${ }^{2}$ (D) Marcos Rogério Mazieri ${ }^{3}$ \\ ${ }^{I}$ PhD Candidate. Universidade Nove de Julho - UNINOVE. São Paulo, SP - Brasil.taina.alves06@ gmail.com \\ ${ }^{2}$ PhD, Full Professor. Universidade Nove de Julho-UNINOVE. São Paulo, SP-Brasil. cdpedron@gmail.com \\ ${ }^{3}$ PhD, Full Professor. Universidade Nove de Julho - UNINOVE. São Paulo, SP - Brasil.marcosmazzzieri@gmail.com
}

\begin{abstract}
Objective of the study: This study aims to analyze scientific production about absorptive capacity and innovation in such a way as to make it possible to identify study trends and the theoretical bases on which they are based. Methodology / Approach: We performed bibliographic coupling, cocitation, and social network analysis on a sample of 3,698 articles, considering 2,778 articles from Web of Science and 920 articles from Scopus.

Originality / Relevance: In a preliminary search, only two bibliometric works were identified that focused on absorptive capacity and innovation. However, since 2015, more than 1,500 articles have been published, with new perspectives, advancing studies on this topic.

Main results: The coupling analysis resulted in six factors showing the trends of future studies. The co-citation analysis presented three factors, representing the intellectual structure arising from the coupling analysis. The network analysis provided insight into how these studies connect. The results point to trends in future studies that can fill the research gaps on absorptive capacity and innovation. In addition, we also indicate the theoretical fronts that can be used to explore these trends. Finally, we present a model that summarizes our findings and shows how they can contribute to the advancement of research based on the seminal model of Zahra and George (2002).

Theoretical / Methodological contributions: We present a mapping of the theme that provides a clearer view of which seminal works are used to approach each theme to be explored in future studies, associating the results of the bibliometric techniques used.
\end{abstract}

Keywords: Absorptive capacity. Innovation. Bibliometrics. Co-citation analysis. Coupling bibliographic.

\section{A EVOLUČ̃O DA CAPACIDADE ABSORTIVA NA LITERATURA CIENTÍFICA: UMA ANÁLISE BIBLIOMÉTRICA FOCADA NA INOVAÇÃO}

\section{Resumo}

Objetivo do estudo: Este estudo visa analisar a produção científica sobre capacidade absortiva e inovação de forma que seja possível identificar as tendências dos estudos e as bases teóricas em que se baseiam.

Metodologia / Abordagem: Realizamos as análises de pareamento, cocitação e redes sociais por meio de uma amostra de 3.698 artigos, considerando 2.778 artigos da Web of Science e 920 artigos da Scopus.

Originalidade / Relevância: Em uma pesquisa preliminar, foram identificados apenas dois trabalhos bibliométricos com foco em capacidade absortiva e inovação. No entanto, mais de 1.500 artigos foram publicados com novas perspectivas, avançando os estudos sobre o tema após 2015.

Principais resultados: A análise de pareamento resultou em seis fatores que mostram as tendências de estudos futuros. A análise de cocitação apresentou três fatores representativos da estrutura intelectual decorrente da análise de pareamento. A análise de redes proporcionou uma visão sobre como esses estudos se conectam. Os resultados apontam para tendências em estudos futuros que podem preencher as lacunas de pesquisas sobre capacidade absortiva e inovação. Além disso, também indicamos as frentes teóricas que podem ser utilizadas para explorar essas tendências. Ao final, apresentamos um modelo que sintetiza nossas descobertas e mostra como elas podem contribuir para o avanço da pesquisa a partir do modelo seminal de Zahra e George (2002).

Contribuições teórico-metodológicas: Apresentamos um mapeamento do tema que permite uma visão mais clara de quais obras seminais são utilizadas para abordar cada tema a ser explorado em estudos futuros, associando os resultados das técnicas bibliométricas utilizadas.

Palavras-chave: Capacidade de absorção. Inovação. Bibliometria. Análise de cocitação. Pareamento bibliográfico.

\section{LA EVOLUCIÓN DE LA CAPACIDAD DE ABSORCIÓN EN LA LITERATURA CIENTÍFICA: UN ANÁLISIS BIBLIOMÉTRICO CENTRADO EN LA INNOVACIÓN}

\begin{abstract}
Resumen
Objetivo del estudio: Este estudio tiene como objetivo analizar la producción científica sobre capacidad absorptiva e innovación de manera que sea posible identificar las tendencias de los estudios y las bases teóricas en las que se sustentan.

Metodología / Enfoque: Realizamos el análisis de emparejamiento, cocitación y redes sociales a través de una muestra de 3.698 artículos, considerando 2.778 artículos de la Web of Science y 920 artículos de Scopus. Originalidad / Relevancia: En una encuesta preliminar, solo se identificaron dos trabajos bibliométricos con un enfoque en la capacidad absorptiva y la innovación. Sin embargo, se publicaron más de 1.500 artículos con nuevas perspectivas, avanzando los estudios sobre el tema después de 2015 .

Resultados principales: El análisis de emparejamiento dio como resultado seis factores que muestran las tendencias de estudios futuros. El análisis de cocitación mostró tres factores representativos de la estructura intelectual resultante del análisis de emparejamiento. Los resultados apuntan a tendencias en estudios futuros que pueden llenar los vacíos de investigación sobre la capacidad absorptiva y la innovación. El análisis de redes proporcionó información sobre cómo se conectan estos estudios. Además, también indicamos los frentes teóricos que se pueden utilizar para explorar estas tendencias. Al final, presentamos un modelo que sintetiza nuestros hallazgos y muestra cómo pueden contribuir al avance de la investigación basada en el modelo seminal de Zahra y George (2002).

Aportes teóricos y metodológicos: Presentamos un mapeo de la temática que permite tener una visión más clara de qué obras seminales se utilizan para abordar cada tema a explorar en futuros estudios, asociando los resultados de las técnicas bibliométricas empleadas.
\end{abstract}

Palabras clave: Capacidad absorptiva. Innovación. Bibliometría. Análisis de cocitación. Acoplamiento bibliográfico.

Cite as / Como citar

American Psychological Association (APA

Townsend, T. A., Pedron, C. D., \& Mazieri, M. R. (2021). The evolution of absorptive capacity in the scientific literature: a bibliometric analysis focused on innovation. Iberoamerican Journal of Strategic Management (IJSM), 20, 1-31, e18752. https://doi.org/10.5585/riae.v20i1.18752.

$(A B N T-N B R 6023 / 2018)$

Townsend, Tainá Alves; Pedron, Cristiane Drebes; Mazieri, Marcos Rogério. The evolution of absorptive capacity in the scientific literature: a bibliometric analysis focused on innovation. Iberoamerican Journal of Strategic Management (IJSM), v. 20, p. 1-31. 2021. https://doi.org/10.5585/riae.v20i1.18752. 


\section{Introduction}

The absorptive capacity concept was first coined by Cohen and Levinthal (1990) and there have been significant developments in the concept and measurement ever since (Albort-Morant, LealRodríguez, \& De Marchi, 2018). This capacity represents an essential part of a company's ability to create new knowledge (Cohen \& Levinthal, 1990) and is vital for its innovation activities (Xie, Zou \& Qi, 2018). Activities related to developing new products or services in an organization are sophisticated and timeless (Limaj \& Bernroider, 2017). Many previous studies have indicated that absorptive capacity contributes directly or indirectly to an organization's innovation and financial performance (Xie et al., 2018).

Other current researchers suggest developing absorptive capacity as the total dynamic capacity to improve innovation in organizations. There are, therefore, theoretical tensions which could be better understood, leading to interest in this article to provide better positioning of absorptive capacity and its potential contributions to the innovation of companies. These theoretical tensions can be explained due to the ambiguity between absorptive capacity and the dynamic capacities. If absorptive capacity is a part of what we know as dynamic capabilities, the boundaries are unclear, as are the other known dynamic capabilities, and it becomes more difficult to identify the effects and contributions of absorptive capacity to the innovation of organizations. If absorptive capacity is part of the knowledge transfer processes, such processes have been little explored in the specific literature on organizational innovation or it could be that such publications have not been properly structured for the purposes of analysis. When we examine the literature that deals with organizational routines, we find both theoretical interconnection with absorptive capacity and other constructs linked to organizational networks. The existence of extensive literature dealing with capacity in different ways, but with little exploration regarding a possible theoretical organization of the theme directly related to organizational innovation, justifies this bibliometric study.

In contrast to the abundant research on how companies absorb technological knowledge, there is little mention in the management literature about the ability of companies to absorb the knowledge needed to generate innovation (Schweisfurth \& Raasch, 2018). This and other gaps need to be better identified and, for this, it is necessary to look at the intellectual structure and research trends on this theme.

The advancement in scientific productions arises from exploring knowledge from previous studies and the interaction between researchers over time. Knowing the concepts, the evolution of the theme over time, the leading scholars, and the literary production of greatest relevance can aid understanding of the existing theory. Therefore, analyzing the history of publications could help researchers to establish what has been studied on the subject and identify opportunities for future research. 
In a preliminary consultation based on the Web of Science (2019), we found only two bibliometric works focused on absorptive capacity and innovation. Subsequently, Seguí-Mas, SignesPérez, Sarrión-Viñes, and Alegre Vidal (2016) developed a bibliometric to identify whether there was any relationship between absorptive capacity and a specific type of innovation: open innovation. Later, Rossetto, Carvalho, Bernardes, and Borini (2017) sought to present an overview of international scientific publications on absorptive capacities and innovation to map the academic contributions made between 1990 and 2015 (25 years). However, since 2015, more than 1,500 articles have been published, with new perspectives, advancing studies on this topic.

Considering the arguments presented, the following research question was proposed: How does absorptive capacity impact the innovation literature? To answer this question, the main objective of the current article was to analyze scientific production about absorptive capacity and innovation in such a way that it is possible to identify study trends and the theoretical bases on which they are based. Thus, the specific objectives were: (1) to identify relevant studies that may point to future studies related to absorptive capacity and innovation; and (2) to identify the studies that lead researchers to the intellectual structure of research on these trends.

Methodologically, a bibliometric study was developed using a sample of 3,180 articles collected from the Web of Science and Scopus databases. The coupling and co-citation analyses were then performed to derive the subfields of the study and research opportunities involving the intersection between absorptive capacity and innovation. The coupling analysis resulted in 6 factors that reflect trends for future studies, while the co-citation analysis showed, in 3 factors, the intellectual structure that underlies these trends.

The results show the trends of themes to be studied to fill gaps in the knowledge on absorptive capacity and innovation. As a differential compared to other bibliometric studies developed on this topic, we combine the results of the co-citation and coupling analysis to enable the recommendation of the intellectual structure to be used to respond to these gaps and present network diagrams to show how these studies are connected in each analysis. Finally, we present a model that summarizes our findings and shows how they can contribute to the advancement of research based on the seminal model of Zahra and George (2002).

\section{Methodological procedures}

\subsection{Method}

A bibliometric method can be characterized as a series of techniques that seek to quantify the process of written communication and analyze some attributes and behaviors of published information (Okubo, 1997). As this method is a quantitative instrument that allows minimization of the subjectivity of the analyses, it was adopted to map the intellectual structure of this field. Thus, insights are also 
provided on the main opportunities for publication, establishing a reference for the study of trends and emerging paradigms in absorptive capacity and innovation research.

\subsection{Data collection}

We performed searches of publications available on Web of Science and Scopus, through the terms "absorptive capacity*" AND "innovat*" (in quotation marks and with the asterisk). The period was not defined because the objective was to map all the information available in the databases until the end of 2019. The sample was delimited to consider only articles because these types of documents go through the review process blindly and in pairs. The database results were restricted to documents available in English, and published in business or management categories. A total of 2,778 articles were found in Web of Science and 920 articles in Scopus, totaling 3,698 articles found.

A total of 518 articles that did not present abstracts or references, or were duplicated in the databases were removed. Thus, the sample used for this study was composed of 3,180 articles. The protocols suggested by the Iberoamerican Journal of Strategic Management (IJSM) and Brazilian Journal of Marketing (BJM) were used to carry out this study (Quevedo-Silva, Santos, Brandão, \& Vils, 2016; Serra, Cirani, \& Moutinho, 2019; Serra et al., 2018).

\subsection{Research sample}

The sample of this study consisted of 3,180 articles published in 433 journals. In general, publications on absorptive capacity and innovation increased in the period analyzed (Figure 1). The first study was published in 1986. Only 478 articles were published on the subject in the first 20 years (1986 to 2009), reaching a maximum of 109 articles in 2009. The period from 2010 to 2019 showed significant growth, with an average of 270 publications per year.

Figure 1 - Evolution of scientific publications by year

Total of Publications

3,180 
The articles were published in 433 journals, and the 20 journals with the highest volume of publications accounted for approximately 45.13 percent (1,435 articles) of the scientific production analyzed. The journals that stand out for this theme are Research Policy (SJR 3,409), Technological Forecasting and Social Change (SJR 1,422), and Journal of Business Research (SJR 1,684). Table 1 shows the list of the main journals identified.

Table 1 - Journals that published the most articles on Absorptive Capacity and Innovation (1986 - 2019)

\begin{tabular}{clccc}
$\#$ & \multicolumn{1}{c}{ Journal } & Articles & $\%$ & $\%$ Accumulated \\
\hline 1 & Research Policy & 166 & $5.22 \%$ & $5.22 \%$ \\
2 & Technological Forecasting and Social Change & 111 & $3.49 \%$ & $8.71 \%$ \\
3 & Journal of Business Research & 100 & $3.14 \%$ & $11.86 \%$ \\
4 & Journal of Knowledge Management & 91 & $2.86 \%$ & $14.72 \%$ \\
5 & Technology Analysis \& Strategic Management & 89 & $2.80 \%$ & $17.52 \%$ \\
6 & Strategic Management Journal & 84 & $2.64 \%$ & $20.16 \%$ \\
7 & Technovation & 83 & $2.61 \%$ & $22.77 \%$ \\
8 & International Journal of Technology Management & 78 & $2.45 \%$ & $25.22 \%$ \\
9 & International Journal of Innovation Management & 77 & $2.42 \%$ & $27.64 \%$ \\
10 & R \& D Management & 75 & $2.36 \%$ & $30.00 \%$ \\
11 & Journal of Product Innovation Management & 67 & $2.11 \%$ & $32.11 \%$ \\
12 & Journal of Technology Transfer & 65 & $2.04 \%$ & $34.15 \%$ \\
13 & Industry and Innovation & 56 & $1.76 \%$ & $35.91 \%$ \\
14 & Management Decision & 53 & $1.67 \%$ & $37.58 \%$ \\
15 & Industrial Marketing Management & 48 & $1.51 \%$ & $39.09 \%$ \\
16 & Journal of Engineering and Technology Management & 41 & $1.29 \%$ & $40.38 \%$ \\
17 & International Business Review & 40 & $1.26 \%$ & $41.64 \%$ \\
18 & Asian Journal of Technology Innovation & 37 & $1.16 \%$ & $42.80 \%$ \\
19 & Knowledge Management Research \& Practice & 37 & $1.16 \%$ & $43.96 \%$ \\
20 & Organization Science & 37 & $1.16 \%$ & $45.13 \%$ \\
Other 413 Scientific Journals & 1,747 & $54.87 \%$ & $100.00 \%$ \\
\hline
\end{tabular}

Source: Research Data - Scopus and Web of Science.

The sample also included 5,385 authors involved in the publications. However, a concentration of publications is evident, with 6 authors contributing 15 or more studies (Lichtenthaler, Li, Roper, Molina-Morales, Volberda, and Zahra). Van der Bosch, Volberda and Zahra are examples of authors who have published the most on this theme and also have studies with huge impact in the literature about absorptive capacity. Table 2 presents the list of the most productive authors on this theme, considering those that presented more than 11 articles.

Table 3 shows the number of articles separated by citation ranges. It was observed that 227 articles (7.14\% of the sample) presented more than 100 citations according to the count of the Scopus and Web of Science databases, reinforcing that the theme has been widely discussed in the literature. More than 56\% of the articles presented between 0 and 10 citations, which could be a reflection of the number of articles published more recently (last 5 years). Less than $1 \%$ (20 articles) of the articles presented more than 500 citations, mainly because this includes most of the seminal works on this theme. 
Table 1 - Authors with at least 10 articles found in the analyzed sample

\begin{tabular}{ccccc}
\hline Author & Articles & & Author & Articles \\
\cline { 1 - 2 } \cline { 4 - 5 } \cline { 4 - 5 } Lichtenthaler U & 25 & & Duysters G & 12 \\
Li J & 17 & & George G & 12 \\
Roper S & 17 & & Laursen K & 12 \\
Molina-Morales FX & 16 & & Belderbos R & 11 \\
Volberda HW & 15 & & Blind K & 11 \\
Zahra SA & 15 & & Brettel M & 11 \\
Chen CJ & 14 & & Kang J & 11 \\
Li Y & 14 & & Ning LT & 11 \\
Vanhaverbeke W & 14 & & Rothaermel FT & 11 \\
Petruzzelli AM & 13 & & Van den Bosch FAJ & 11
\end{tabular}

Source: Research Data - Scopus and Web of Science.

Table 2 - Number of articles identified by citation ranges

\begin{tabular}{ccc}
\hline Number of Citations & Articles & $\%$ \\
\hline Above 500 citations & 20 & $0.63 \%$ \\
401 - 500 citations & 15 & $0.47 \%$ \\
$301-400$ citations & 12 & $0.38 \%$ \\
$201-300$ citations & 51 & $1.60 \%$ \\
$101-200$ citations & 129 & $4.06 \%$ \\
$91-100$ citations & 30 & $0.94 \%$ \\
81 - 90 citations & 32 & $1.01 \%$ \\
71 - 80 citations & 42 & $1.32 \%$ \\
\hline Source: Research Data - Scopus and Web of Science.
\end{tabular}

\begin{tabular}{ccc}
\hline Number of Citations & Articles & $\%$ \\
\hline 61 - 70 citations & 50 & $1.57 \%$ \\
$51-60$ citations & 73 & $2.30 \%$ \\
41 - 50 citations & 94 & $2.96 \%$ \\
31 - 40 citations & 154 & $4.84 \%$ \\
21 - 30 citations & 252 & $7.92 \%$ \\
11 - 20 citations & 431 & $13.55 \%$ \\
$1-10$ citations & 1315 & $41.35 \%$ \\
No citations & 480 & $15.09 \%$ \\
\hline
\end{tabular}

\subsection{Data analysis}

Among the different types of analyses that can be performed in a bibliometric study, we chose to perform coupling and co-citation analysis. Bibliographic coupling is a measure of similarity based on the frequency that two documents in the sample share at least one standard reference. In this sense, the documents in a sample are grouped according to the overlap of their bibliographies (Vogel \& Güttel, 2013; Zupic \& Čater, 2015). The coupling analysis allowed identification of the most commonly shared references among the authors who published about absorptive capacity and innovation. This analysis is useful for detecting trends and possible paths to a field related to publication, indicating the research front in a field (Zupic \& Čater, 2015).

The analysis of co-citation is another way to analyze the citation structure and provides a glimpse of the relations between the works, representing the knowledge base in the field (Serra et al., 2018). Co-citation is defined as the frequency with which two documents are cited together in the literature (Vogel \& Güttel, 2013). The analysis of co-citation and coupling differs from the analysis level: while co-citation represents a similar relationship between two cited publications, bibliographic coupling is a measure of association between two cited publications (Vogel \& Güttel, 2013). While cocitation is a reliable indicator of the publication impact, bibliographic coupling measures publishing 
activity (Vogel \& Güttel, 2013). We also present the social network analysis from the results of coupling and co-citation analysis, representing the network formations in a diagram and providing a confirmatory analysis of the cohesion index (Levine \& Kurzban, 2006).

Preparation and analysis of the sample were performed using Bibexcel, SPSS, Ucinet, and Microsoft Excel as support tools. BibExcel is a toolbox that facilitates the generation of data files from Excel for further analysis (Liu \& Gui, 2016). The use of this tool was especially important to provide accurate results. This is because databases are usually extracted with problems of format and standardization of information (such as authors' names written differently and letters in higher/lower case), which can generate results and counts different from the reality of the research field studied. Bibexcel allows the researcher to identify these failures and manage the results appropriately.

\section{Results}

The results generated from the methodological procedures are presented in two topics. The first topic describes the results of the bibliographic coupling analysis that sought to highlight subjects that are trends for new studies. The second topic brings the findings of the co-citation analysis, carried out based on the references of the articles found in the bibliographic coupling analysis. This latter topic contributes to the mapping of the theoretical structure that supports the trends of future studies on absorptive capacity and innovation. We also presented social network analysis on both topics, showing the link between the articles.

\subsection{Coupling analysis}

We generated a coupling matrix with the support of Bibexcel and initially considered the standard volume of 1,001 correlated references. However, the high volume of references would make any bibliometric analysis that could respond to the research objectives impossible. Therefore, we defined two cutting criteria to focus the analysis on the most relevant articles. The first criterion used was the number of relationships between the references. After applying this criterion, all references that presented 24 or more relationships with other articles were maintained in the matrix, totaling 100 references. The second criterion of sample reduction was to exclude references from the network analysis, as suggested by Vogel and Gutel (2012). For this, we used Ucinet software to generate the network design from the matrix of 100 articles. Relationships higher than eight and the exclusion of isolated references (which were not linked to any other reference) and pedants (which connected with only one reference) were considered. Thus, the reduced version of the matrix considered 84 references.

When performing the coupling matrix analysis, we perceived that the higher the number of references shared by two documents in a sample, the higher the similarity between them. This similarity approximates the sample items, generating a factor that can determine a path that the study field is taking. To identify these factors, we chose to perform exploratory factor analysis. The procedure 
recommended by Hair et al. (2009) for the performance of the exploratory factor analysis is to evaluate the KMO (above 0.5) of each item in the anti-image matrix, the general KMO (above 0.5), the exclusion of items with commonality below 0.5 , the exclusion of items with a load below 0.5 in a factor, and items with crossloads (above 0.5 in more than one factor). At each exclusion, the procedure was followed from the beginning in this order of analysis, always considering the main components and the Varimax rotation method. At the end of the extractions, we observed a general KMO of 0.816. Furthermore, six factors corresponding to $60.94 \%$ of the Explained Variance were identified, above the $60 \%$ indicated by the literature (Hair et al., 2009). The internal reliability measurement of each factor (Cronbach's Alpha) was also evaluated, accepting all factors because they had values higher than 0.6. The 34 articles referring to the six factors and their crossloads are shown in Table 4.

The articles in Factor 1 concern interorganizational knowledge networks. Some previous studies argue that a company's absorptive capacity plays a critical role in collaborative innovation and interorganizational relationships and can lead to a significant competitive advantage (Kaur \& Mehta, 2016; Zhang, Zhao, Lyles, \& Guo, 2015). If an organization is considered a system, knowledge is its input, and the capacity for innovation is its output (or result) (Kaur \& Mehta, 2016).

The innovation literature documents that the structural positions of companies in interorganizational collaboration networks matter to innovation (Dong \& Yang, 2016). These networks serve as relational exchanges with peers (competitors), customers, and suppliers, which can be a critical source of knowledge, leading to innovation (Hao \& Feng, 2016). Three measures for the centrality of the knowledge network have been used to measure the impact of the network on developing new products: degree centrality, proximity centrality, and vector centrality (Dong \& Yang, 2016).

Some authors argue that different types of network may perform differently by providing access to specific knowledge sets (Hao \& Feng, 2016). Previous studies on innovation in interorganizational networks have focused primarily on collaboration networks based on alliance partnerships (Dong \& Yang, 2016). The literature points to three types of network ties in the context of interorganizational networks: (1) purchasing ties, when companies within networks are involved in buyer and supplier relationships, (2) peer collaboration ties, when companies build collaborative relationships with competitors, and (3) equity ties, when collaborative partners hold each other's equity interests (Hao \& Feng, 2016). However, it is worth noting that knowledge networks are different from collaboration networks, as the latter are relationship-based and not knowledge-based (Dong \& Yang, 2016).

Other studies highlight the importance of companies assimilating external knowledge of interorganizational networks to benefit their new product development activities (Dong \& Yang, 2016; Hao \& Feng, 2016; Ojo \& Raman, 2016; Volberda et al., 2016). Some studies have sought to understand how companies acquire the technological foundation to quickly upgrade and move from one set of advanced products and technologies to another, focusing both on the build-up of technological capabilities and the underlying absorptive capacity of each company (Chuang \& Hobday, 2013; DíezVial \& Fernández-Olmos, 2015). However, existing studies have neglected the underlying role of 
individuals and the effects of individual differences on the associated dimensions of absorptive capacity

(Ojo \& Raman, 2016).

Table 4 - Exploratory factor analysis from the coupling matrix (highlighting loads of 0.4 or higher)

\begin{tabular}{|c|c|c|c|c|c|c|}
\hline Author(s), Year & Factor 1 & Factor 2 & Factor 3 & Factor 4 & Factor 5 & Factor 6 \\
\hline Chalmers and Balan-Vnuk (2013) & 0,802 & 0,114 & $-0,149$ & 0,135 & $-0,087$ & $-0,020$ \\
\hline Hao and Feng (2016) & 0,771 & 0,147 & $-0,029$ & 0,233 & $-0,047$ & $-0,019$ \\
\hline Zhang et al. (2015) & 0,750 & 0,004 & $-0,049$ & 0,268 & $-0,102$ & $-0,020$ \\
\hline Dong and Yang (2016) & 0,748 & 0,111 & 0,091 & $-0,170$ & $-0,082$ & 0,033 \\
\hline Chuang and Hobday (2013) & 0,742 & 0,023 & $-0,002$ & 0,242 & 0,393 & $-0,081$ \\
\hline Diez-Vial and Fernandez-Olmos (2015) & 0,733 & $-0,053$ & $-0,075$ & 0,103 & $-0,083$ & 0,038 \\
\hline Ojo and Raman (2016) & 0,728 & 0,054 & $-0,015$ & 0,387 & $-0,049$ & $-0,008$ \\
\hline Kaur and Mehta (2016) & 0,674 & 0,040 & 0,151 & 0,148 & $-0,044$ & $-0,079$ \\
\hline Wang et al. (2014) & 0,110 & 0,861 & 0,019 & 0,034 & 0,140 & 0,015 \\
\hline Doyle et al. (2014) & $-0,093$ & 0,857 & 0,054 & $-0,075$ & 0,114 & $-0,078$ \\
\hline Cui (2013) & 0,275 & 0,772 & $-0,015$ & 0,132 & 0,224 & $-0,002$ \\
\hline Hu and Hung (2014) & $-0,095$ & 0,733 & 0,097 & $-0,153$ & 0,051 & $-0,077$ \\
\hline Dominguez Gonzalez et al. (2014) & 0,132 & 0,729 & 0,002 & 0,059 & 0,128 & $-0,088$ \\
\hline $\begin{array}{l}\text { Fernandez Perez and Gutierrez Gutierrez } \\
\text { (2013) }\end{array}$ & $-0,098$ & 0,686 & 0,102 & $-0,120$ & 0,090 & $-0,111$ \\
\hline Raymond et al. (2016) & 0,246 & 0,663 & 0,075 & $-0,021$ & $-0,045$ & $-0,035$ \\
\hline Ratten (2016) & $-0,117$ & $-0,020$ & 0,792 & 0,022 & 0,018 & $-0,046$ \\
\hline Lucena (2016) & $-0,093$ & $-0,032$ & 0,739 & $-0,138$ & $-0,032$ & $-0,050$ \\
\hline Ahlin et al. (2014) & $-0,069$ & 0,194 & 0,718 & 0,378 & $-0,039$ & $-0,011$ \\
\hline Datta (2016) & 0,172 & 0,004 & 0,717 & 0,186 & $-0,039$ & $-0,025$ \\
\hline Xie et al. (2014) & $-0,029$ & 0,121 & 0,705 & 0,162 & 0,031 & $-0,061$ \\
\hline Lin and Chang (2015a) & 0,083 & $-0,051$ & 0,689 & 0,318 & $-0,011$ & 0,082 \\
\hline Pilav-Velic and Marjanovic (2016) & $-0,035$ & 0,133 & 0,679 & 0,198 & 0,121 & 0,027 \\
\hline Cozza and Zanfei (2016) & 0,177 & 0,340 & 0,532 & 0,375 & $-0,043$ & 0,102 \\
\hline Gressgard et al. (2014) & 0,176 & $-0,060$ & 0,110 & 0,698 & $-0,032$ & $-0,001$ \\
\hline Lin and Chang (2015b) & 0,232 & $-0,166$ & 0,111 & 0,697 & $-0,088$ & 0,015 \\
\hline Agarwal and $\mathrm{Wu}(2015)$ & 0,094 & $-0,101$ & 0,369 & 0,689 & $-0,033$ & 0,016 \\
\hline Martinez-Torres and Olmedilla (2016) & 0,212 & 0,109 & 0,311 & 0,684 & $-0,106$ & $-0,071$ \\
\hline Spanos et al. (2015) & 0,223 & 0,000 & 0,242 & 0,588 & $-0,088$ & $-0,047$ \\
\hline Huang et al. (2014) & $-0,071$ & 0,111 & $-0,036$ & $-0,139$ & 0,827 & $-0,019$ \\
\hline Karamanos (2016) & $-0,067$ & 0,262 & 0,016 & $-0,081$ & 0,798 & $-0,038$ \\
\hline Ebers and Maurer (2014) & $-0,077$ & 0,175 & 0,065 & $-0,053$ & 0,764 & $-0,119$ \\
\hline Blind and Mangelsdorf (2016) & $-0,055$ & $-0,038$ & $-0,128$ & $-0,132$ & $-0,019$ & 0,895 \\
\hline Garavan et al. (2016) & $-0,068$ & $-0,105$ & $-0,066$ & $-0,062$ & $-0,063$ & 0,860 \\
\hline Lee (2016) & 0,063 & $-0,291$ & 0,259 & 0,297 & $-0,173$ & 0,729 \\
\hline General KMO & \multicolumn{6}{|c|}{0,816} \\
\hline Eigenvalues & 5,090 & 4,559 & 4,420 & 3,399 & 2,297 & 2,174 \\
\hline$\%$ Variance & 14,14 & 12,66 & 12,28 & 9,44 & 6,38 & 6,04 \\
\hline$\%$ Cumulative Variance & 14,14 & 26,80 & 39,08 & 48,52 & 54,90 & 60,94 \\
\hline Cronbach's Alpha Coefficient & 0,89 & 0,88 & 0,85 & 0,79 & 0,77 & 0,81 \\
\hline Number of articles in each factor & 8 & 7 & 8 & 5 & 3 & 3 \\
\hline Density & 0,889 & 0,875 & 0,889 & 0,833 & 0,750 & 0,750 \\
\hline Cohesion & 0,855 & 0,838 & 0,868 & 0,776 & 0,685 & 0,621 \\
\hline
\end{tabular}

Source: Search data - Coupling matrix. 
Factor 2 concerns the life cycle of alliances and the influence of the upper echelon (Chief Executive Officers - CEO). Knowledge management is mainly focused on connecting people, processes, and technology to expand corporate knowledge (Gonzalez et al., 2014). The main characteristics of a sector, including its knowledge, its capabilities, its stakeholders, its interactions, and its particular institutions, form the essential elements that can help understand innovation activities in terms of their locations, and national and global dimensions (Hu \& Hung, 2014; Raymond, Bergeron, Croteau, \& St-Pierre, 2016). Thus, knowledge needs to be managed within the organizational structure, given the importance of this resource for maintaining competitiveness (Gonzalez et al., 2014).

Alliances are known to be short-lived, with an estimated termination rate of more than $50 \%$ within four years after formation, and many companies are involved in multiple alliances with different partners, forming portfolios of alliances (Cui, 2013). Thus, organizations must create environments that encourage and facilitate knowledge sharing, emphasizing the role of organizational structure and culture as facilitators of this process (Gonzalez et al., 2014). Some studies have adopted a portfolio perspective to examine the interdependencies between multiple alliances of a company, often observing the differences and similarities between different partner resources (Cui, 2013).

Another particularly prominent theme concerns the role of upper echelon social networks in promoting strategic flexibility and organizational learning, highlighting the importance of managers, notably CEOs, in driving strategic changes in companies (Pérez \& Gutiérrez Gutiérrez, 2013). Some authors state that much of the knowledge is not explicitly codified, remaining untold, and manifesting itself as competencies and abilities of individuals (Gonzalez et al., 2014). In this context, CEO social networks act as a channel for the transmission of information, resources, and opportunities that could be leveraged to aid companies' capacities, such as strategic flexibility and organizational learning (Pérez \& Gutiérrez Gutiérrez, 2013).

Factor 3 presents the structural aspects of alliances, ambidextrous innovation, and entrepreneur networks. Companies are required to generate innovation streams, defined as a company's ability to simultaneously produce incremental and radical innovations, compete effectively in the short term, and survive in the long term (Lucena, 2016). While it is widely recognized that internal Research and Development (R\&D) departments is a crucial source of the ability to absorb, select, and use external knowledge, severe data limitations prevent it from capturing differences between companies in this regard (Cozza \& Zanfei, 2016). In this sense, R\&D alliances and market-based businesses allow companies to improve the possibilities of combining different types of R\&D activities in alternative modes, thus favoring that new complementarities in the production of innovation flows may emerge (Lucena, 2016).

Organizations do not have to adopt innovation but can respond to it by investing in the area of interest (Ratten, 2016). To study these issues, the mode of interaction (cooperative and contract agreements) and the geographical scope of technological alliances (international and domestic partnerships) are introduced as two new criteria for defining sources of exploration and exploitation 
(Lucena, 2016). Companies without structural divisibility may have difficulty finding these sources, suggesting that large companies can better achieve ambidexterity than small and medium-sized enterprises (Lin \& Chang, 2015a).

By controlling internal R\&D efforts, not all companies are equally likely to have access to external technology and knowledge of universities in particular (Cozza \& Zanfei, 2016). For example, organizational and strategy studies have generally recognized that political ties (social connections with governments and government-affiliated agencies) influence new products (Xie, Liu, \& Gao, 2014). Thus, competitive advantage is obtained through partnerships, accessing new and complementary knowledge, and exclusive resources that are not available internally (Pilav-Velić \& Marjanovic, 2016).

Innovative companies often look beyond their industry in search of opportunities to diversify their knowledge related to new technologies and innovations (Datta, 2016). The theory of organizational learning explains that companies transform the value of political ties into innovative new products through organizational learning (Xie et al., 2014). In other words, companies need to extend their borders to explore innovations outside their industries and be able to apply their technological knowledge in order to transcend the mere definition of technological knowledge (Datta, 2016).

The production of innovation flows requires companies to produce new knowledge and use existing knowledge sources (Lucena, 2016). What is currently agreed is that the most successful innovative companies invest in a breadth of accumulated knowledge and absorb information from all kinds of sources - not only internal but also all available external sources (Ahlin et al., 2014). This is due to leadership characteristics related to the idea of challenging current practices, being an essential component of the innovation process (Ratten, 2016).

Management determinants of innovation involve focusing on the personality and behavior of managers regarding how they influence innovation (Ratten, 2016). The knowledge accumulated through internal and external networks of a multinational group is generally available to the parent company and, eventually, to each subsidiary at a lower cost than through arms-length transactions and can complement the available absorptive capacity at the level of each company (Cozza \& Zanfei, 2016). However, several studies on entrepreneurship address the role of networks in smaller enterprises, as this is one way that small and medium-sized entrepreneurs deal with the responsibility of knowledge creation (Ahlin et al., 2014).

Factor 4 addresses the theme of technological diversification and new perspectives on innovation. As suggested by the organizational learning literature, the way a company identifies and manages its technological knowledge bases will be determined by its absorptive capacity (Lin \& Chang, 2015b). Unlike institutions that ultimately tend to isomorphism, individual and institutional entrepreneurs seek unique opportunities and creative business models (Agarwal \& Wu, 2015). Among the diverse organizational capabilities, a company's absorptive capacity is particularly crucial for technology integration and knowledge (Lin \& Chang, 2015b). In particular, the relevance of the ability to assimilate and exploit for its benefit the knowledge generated in the context of collaborative R\&D 
has been discussed in the literature (Spanos et al., 2015), as well as the ability to exploit knowledge of resources, which is fundamental to the innovation capacities of organizations (Gressgård et al., 2014).

Technology has evolved rapidly in recent decades, and technological diversification is widely regarded as a vehicle for organizational growth (Lin \& Chang, 2015b). In this scenario, the strategic behavior of companies from various sectors has been studied from different perspectives to understand the factors that may or may not influence this evolution. For example, normative isomorphism is seen among companies influenced by informal institutions that arise externally, such as perceived subjective norms (i.e., competitors or government), or internally, from social references within the company (Agarwal \& Wu, 2015). Some authors argue that public intervention is necessary to face systemic failures that block the functioning of innovation systems due to conflicting incentives between companies and public sector organizations, institutional rigidities stemming from narrow specialization, asymmetric information, and lack of networking (Spanos et al., 2015). However, these external pressures eventually lead to industry standards and best practice models, reflecting the industry's absorptive capacity (Agarwal \& Wu, 2015).

As technological innovation increasingly plays a central role in the modern business environment, investigating the relationship between technological diversification and steady performance deserves more theoretical and empirical efforts, and this subject may be especially important in large companies (Lin \& Chang, 2015b). Thus, new perspectives on innovation have been created, such as user/customer-based innovation, open innovation, design-oriented innovation, and employee-oriented innovation (Gressgård et al., 2014). These perspectives are different from aligning innovation with user needs (in the sense of innovation market research), which will act as an active designer in the innovation process and indirectly help reduce uncertainty about the market (MartinezTorres \& Olmedilla, 2016). On the other hand, it is also recognized that the impacts of information and communication technologies (ICT) based tools depend on individual and organizational factors. As an example, some studies suggest that the emergence of internet technologies may mitigate the role of gatekeepers (i.e., people who connect internal networks to external sources of information) in the innovation process (Gressgård et al., 2014).

Factor 5 addresses organizational learning and business model innovation. The literature traditionally views innovation as new products, new technologies, or alternative administration and service (Huang et al., 2014). The theory of organizational learning and the resource-based theory of strategic alliances highlight the critical link between learning through alliances and innovation (Karamanos, 2016). Previous studies on team learning focused primarily on the effects of learning behavior or learning activities; however, relatively few empirical studies are available on learning models (Huang et al., 2014).

Business model innovation is one of many innovation strategies adopted by several highly successful corporations, including Apple, Walmart, and FedEx, and small and medium-sized enterprises (Huang et al., 2014). Some researchers have used network theories to understand how networks and 
knowledge structures affect the exploration and production of innovation in specific contexts (Karamanos, 2016). In general, studies on the micro-foundations of the absorptive capacity of organizations have been neglected to date. Little is known about how absorptive capacity arises from the actions and interactions of lower-level actors, such as individuals, teams, or business units (Ebers \& Maurer, 2014).

In terms of the relationship between team learning and organizational learning, team learning is considered a gateway to organizational learning, as it connects the transfer of individual learning to organizational knowledge that can then be shared by all (Huang et al., 2014). Some authors have theorized and empirically demonstrated that absorptive capacity emerges as the unintended consequence of incorporating the organization's external and internal knowledge and its relational empowerment (Ebers \& Maurer, 2014). This highlights the importance of learning through external collaborations (such as strategic alliances) to produce innovation (Karamanos, 2016). Aligning multiple team learning models with organizational innovation should help create competitive advantage, and although the literature aids in the explanation of some complicated questions about organizational learning, many more studies are needed to identify specific learning models (Huang et al., 2014).

Factor 6 points to research on the strategic development of human resources, standardization, and best knowledge sharing practices. To date, the theory of strategic development of human resources has highlighted the primacy of human capital for organizational performance, and resource-based vision theory has been used to argue that the company's specific human capital will result in sustainable competitive advantage (Garavan et al., 2016). Companies face significant challenges, such as the need to reduce time to market, development, and manufacturing costs, or manage products with more and more technology (Lee, 2016). Through the standardization process, companies can supplement their R\&D department with access to other companies' technological developments and benefit from overflows of unintended knowledge (Blind \& Mangelsdorf, 2016).

The dynamic capabilities perspective helps explain how, under conditions of environmental dynamism, human resource strategic development will need to engage in continuous renewal of its capabilities if it wants to contribute to organizational performance (Garavan et al., 2016). For policymakers, standards - the results of the standardization process - play an essential role in internalizing externalities and achieving the liberalization of international trade (Blind \& Mangelsdorf, 2016). Thus, this current situation encourages the implementation of new management technologies, such as knowledge management and innovation management, to increase competitive advantages (Lee, 2016).

Figure 2 refers to the network diagram that shows the link between the authors identified at the end of the exploratory factor analysis based on the coupling matrix. The red nodes represent Factor 1 (interorganizational knowledge networks), which is central to the study by Zhang et al. (2015). The yellow nodes represent Factor 2 (life cycle of alliances and the influence of the upper echelon), which is central to the study by Dominguez Gonzalez et al. (2014). The blue nodes represent Factor 3 (structural 
aspects of alliances, ambidextrous innovation, and entrepreneur networks), which is central to the study by Xie et al. (2014). The orange nodes represent Factor 4 (technological diversification and new perspectives of innovation), which is central to the study by Agarwal and $\mathrm{Wu}$ (2015). The green nodes represent Factor 5 (organizational learning and business model innovation), which is central to the study by Karamanos (2016). Finally, the turquoise nodes represent Factor 6 (strategic development of human resources, standardization, and best practices of knowledge sharing), which is central the study by Lee (2016).

Figure 2 - Network diagram showing the connections between the items in the coupling analysis

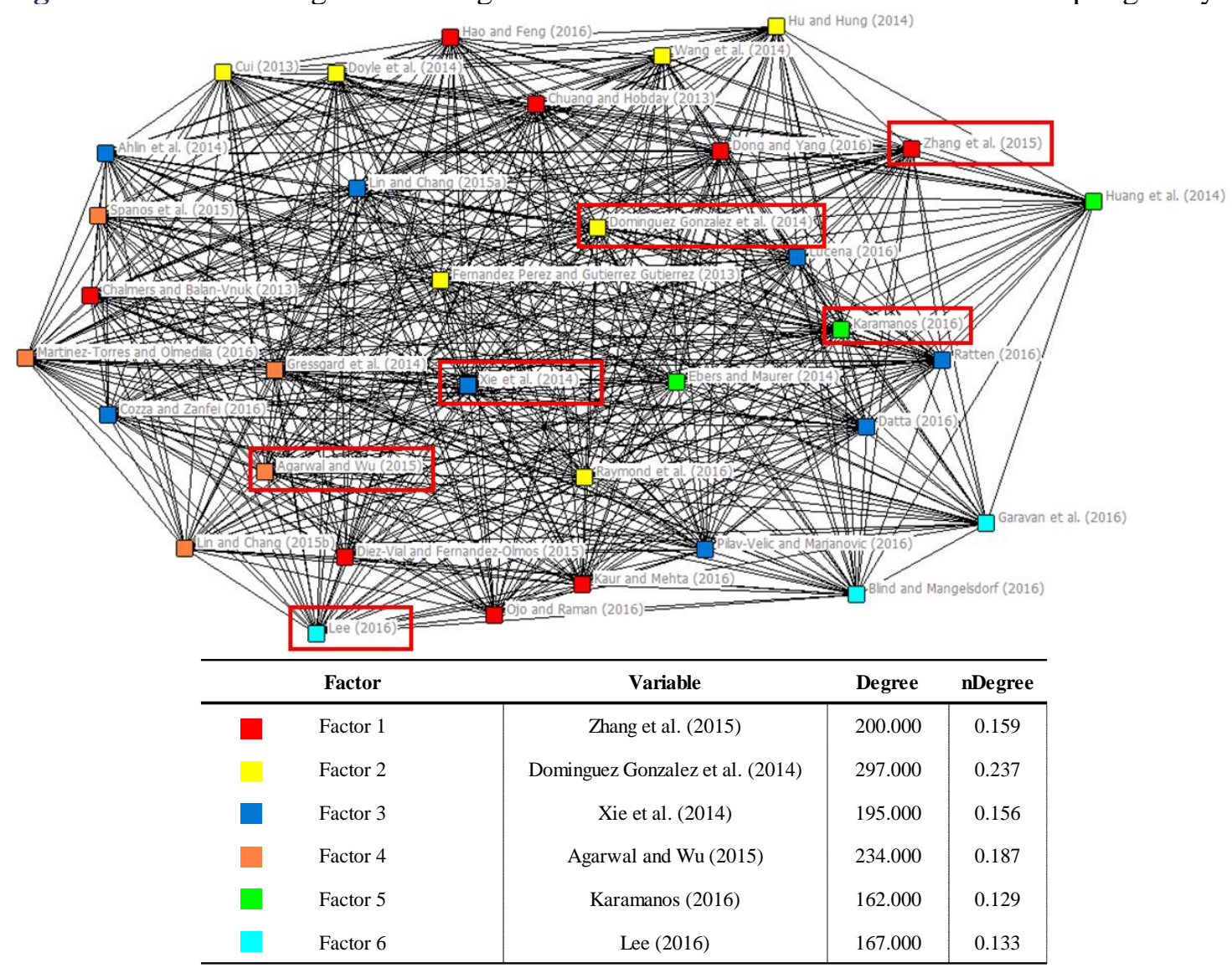

Source: Search data - Coupling matrix.

\subsection{Co-citation analysis}

After analyzing the six factors derived from the coupling matrix, a co-citation matrix was created with the support of Bibexcel to identify studies representing the intellectual structure of the theme studied. This matrix was made from the references of the 34 articles identified in the coupling matrix, which is a way to identify the reasons used for trends in future studies. The references cited in the 34 articles identified in the bibliographic coupling were selected to compose a new dataset. Thus, 53 references were selected because they had more than 5 citations in this dataset. From this dataset, a cocitation matrix was created for mapping the factors. 
To identify the factors that represent this study's intellectual structure, we chose to perform an exploratory factor analysis with the same procedure used to analyze the coupling matrix. The procedures recommended by (Hair et al., 2009) for the performance of the exploratory factor analysis were followed, evaluating the KMO (above 0.5 ) of each item in the anti-image matrix, the general KMO (above 0.5 ), the exclusion of items with commonality below 0.5 , the exclusion of items with a load below 0.5 in a factor, and items with cross loads (above 0.5 in more than one factor). At each exclusion, the procedure was followed from the beginning in this order of analysis, always considering the main components and the Varimax rotation method. At the end of the exploratory factor analysis, a general KMO of 0.918 was observed and three factors were generated from 29 articles, as shown in Table 5.

Factor $\mathbf{A}$ is related to the literature on organizational network structure and knowledge transfer. Some authors state that the dimensions of social interaction and network bonds of social capital are associated with higher knowledge acquisition, while the dimension of relationship quality is negatively associated with the acquisition of knowledge (Yli-Renko et al., 2001). Other authors sought to understand how the dimensions of network social capital affect the transfer of knowledge among members of the network (Inkpen \& Tsang, 2005). The fundamental elements of this factor are the structural hole: a gap between two individuals with complementary resources or information (Burt, 1992). Thus, the acquisition of knowledge, in turn, is positively associated with the exploration of knowledge for competitive advantage through the development of new products, technological differentiation, and sales cost efficiency (Yli-Renko et al., 2001).

Factor $B$ discusses the absorptive capacity and internal and external organizational routines. Some studies claim that the organizational mechanisms associated with coordination resources (multifunctional interfaces, participation in decision-making, and job rotation) mainly improve an organization's potential absorptive capacity (Jansen et al., 2005). The organizational mechanisms associated with socialization capacities (connectivity and socialization tactics) mainly increase the absorption capacity performed by a company (Jansen et al., 2005). Volberda et al. (2016) reviewed the underlying theories and empirical studies of absorptive capacity through bibliometry. The authors argued that realizing the potential of the concept of absorptive capacity requires more research that shows how "micro-antecedents" and "macro-antecedents" influence future results, such as competitive advantage, innovation, and firm performance. Thus, with very few exceptions, the specific organizational routines and processes that constitute the absorptive capacity remain a black box (Lewin, Massini, \& Peeters, 2011).

Factor C portrays organizational learning and technological evolution. While core capabilities are traditionally treated as clusters of distinct technical systems, skills, and management systems, these dimensions of capabilities are deeply rooted in values, which constitute the often neglected but critical fourth dimension (Leonard-Barton, 1992). Among these capabilities, learning has to deal with the challenge of balancing competing objectives of developing new knowledge and exploring current competencies in the face of dynamic trends to emphasize one or the other. According 
to organizational learning research, companies position themselves in a one-dimensional search space that spans a distant local search spectrum (Katila \& Gautam, 2002). In this context, many studies have seen the usefulness of patent citations as a measure of the "importance" of a company's patents, as indicated by the stock market assessment of the company's intangible knowledge stock (Hall, Jaffe, \& Trajtenberg, 2005; Trajtenberg, 1990).

$\underline{\text { Table } 5 \text { - Exploratory factor analysis from the co-citation matrix (highlighting loads of } 0.4 \text { or higher) }}$

\begin{tabular}{|c|c|c|c|}
\hline Author(s), Year & Factor A & Factor B & Factor C \\
\hline Burt (1992) & 0,927 & $-0,097$ & $-0,046$ \\
\hline Argote and Ingram (2000) & 0,919 & $-0,133$ & $-0,077$ \\
\hline Ibarra (1993) & 0,911 & $-0,024$ & $-0,129$ \\
\hline Inkpen and Tsang (2005) & 0,902 & $-0,141$ & -0.050 \\
\hline Uzzi (1997) & 0,902 & $-0,141$ & -0.050 \\
\hline Yli-Renko et al. (2001) & 0,898 & $-0,065$ & 0,036 \\
\hline Granovetter (1973) & 0.890 & 0.060 & $-0,143$ \\
\hline Tsai and Ghoshal (1998) & 0,886 & 0,073 & 0,015 \\
\hline Hansen (1999) & 0,871 & 0,186 & $-0,087$ \\
\hline Nonaka and Takeuchi (1995) & 0,844 & 0,101 & 0,231 \\
\hline Nahapiet and Ghoshal (1998) & 0,854 & 0,196 & 0,041 \\
\hline Reagans and McEvily (2003) & 0,821 & 0,199 & $-0,298$ \\
\hline Lewin et al. (2011) & 0,026 & 0,925 & $-0,031$ \\
\hline Van Der Bosch et al. (1999) & 0,037 & 0,921 & 0,016 \\
\hline Jansen et al. (2005) & $-0,001$ & 0,919 & 0,039 \\
\hline Cohen and Levinthal (1989) & $-0,073$ & 0,913 & 0,018 \\
\hline Volberda et al. (2010) & $-0,009$ & 0,891 & 0,109 \\
\hline Lane et al. (2006) & $-0,016$ & 0,873 & 0,218 \\
\hline Zhao and Anand (2009) & 0,048 & 0.830 & 0,085 \\
\hline Todorova and Durisin (2007) & $-0,112$ & 0,829 & 0,237 \\
\hline Zollo and Winter (2002) & 0,209 & 0,745 & 0,05 \\
\hline Leonard-Barton (1992) & $-0,173$ & 0,207 & 0,886 \\
\hline Levinthal and March (1993) & 0,065 & 0,068 & 0,876 \\
\hline Trajtenberg (1990) & $-0,086$ & $-0,107$ & 0,872 \\
\hline Katila and Ahuja (2002) & 0,019 & 0,212 & 0,863 \\
\hline Hall et al. (2005) & -0.050 & $-0,073$ & 0,856 \\
\hline Nelson and Winter (1982) & $-0,113$ & $-0,054$ & 0,849 \\
\hline Chesbrough (2003) & $-0,166$ & 0,271 & 0,821 \\
\hline Rosenkopf and Nerkar (2001) & 0,123 & 0,291 & 0,791 \\
\hline General KMO & & 0,918 & \\
\hline Eigenvalues & 9,587 & 7,344 & 6,142 \\
\hline$\%$ Variance & 33,06 & 25,32 & 21,18 \\
\hline$\%$ Cumulative Variance & 33,06 & 58,38 & 79,56 \\
\hline Cronbach's Alpha Coefficient & 0,973 & 0,949 & 0,938 \\
\hline Number of articles in each factor & 12 & 9 & 8 \\
\hline Density & 0,923 & 0,900 & 0,889 \\
\hline Cohesion & 0,394 & 0,420 & 0,365 \\
\hline
\end{tabular}

Source: Search data - Co-citation matrix. 
Figure 3 refers to the network diagram that shows the link between the authors identified at the end of the exploratory factor analysis based on the co-citation matrix. The dark red nodes represent Factor A (organizational network structure and knowledge transfer), which is central to the study by Hansen (1999). The green nodes represent Factor B (absorptive capacity and internal and external organizational routines), which is central to the study by Todorova and Durisin (2007). Finally, the dark blue nodes represent Factor C (organizational learning and technological evolution), which is central to the study by Chesbrough (2003).

Figure 3 - Network diagram showing the connections between the items in the co-citation analysis

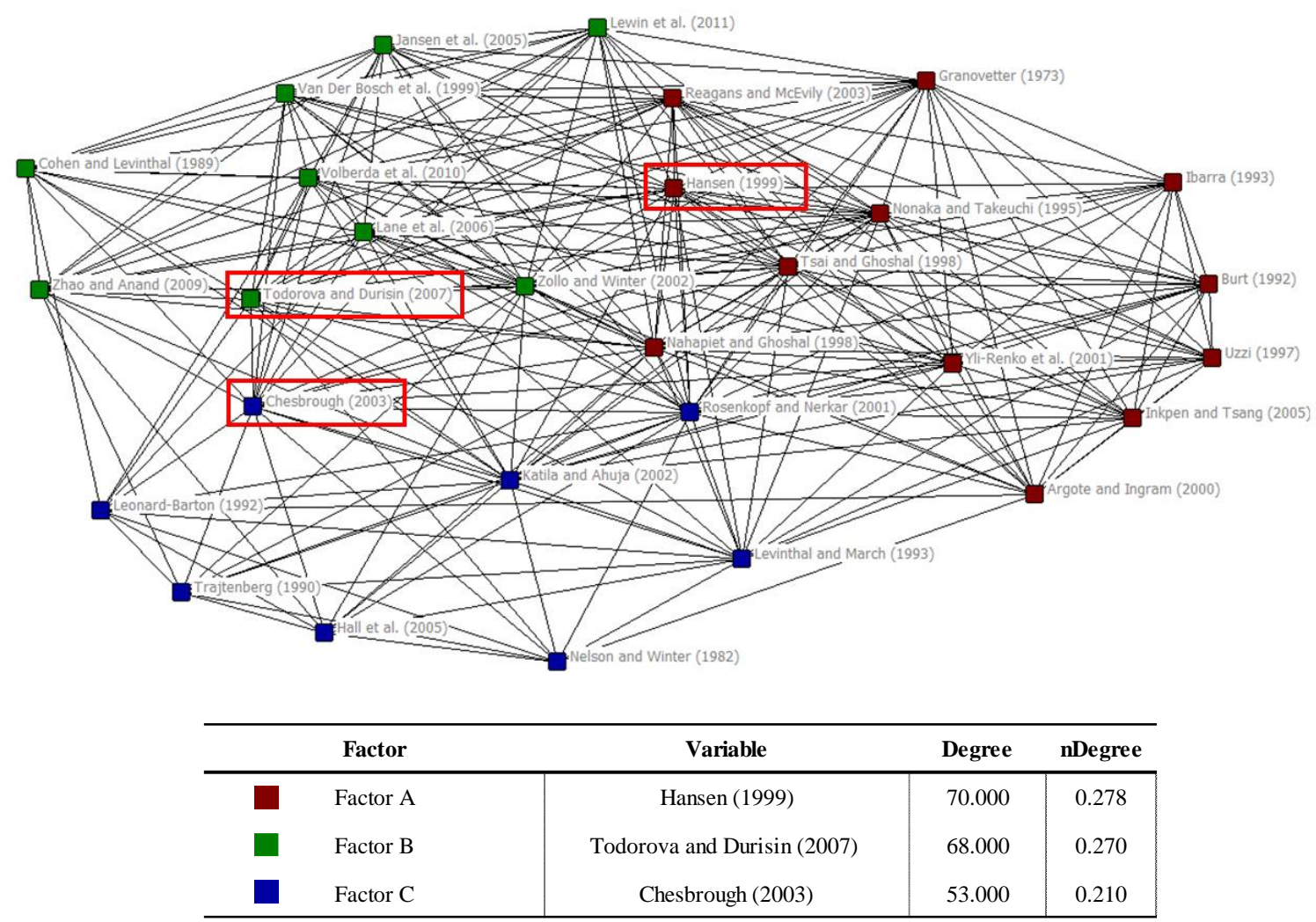

Source: Search data - Co-citation matrix.

\section{Discussions}

By observing the intersection between the factors that make up coupling and co-citation (Figure 4 ), it is possible to deduce a relationship between them. Table 6 shows the normalized relations between the factors of the coupling. This process enables identification of the influence of the intellectual structure, based on the factors defined in co-citation, on forming the coupling (Serra et al., 2019).

In general, we realized that most of the factors related to trends in future studies are explored under the lens of the three factors of intellectual structure. However, there is clearly a predominance of the perspectives being used to explain these phenomena. Only factors 5 and 6 remained in only one or two factors (respectively). Although it is not one of the trends pointed out by the results of this study, new research could evaluate whether it makes use of theoretical lenses that have not yet been suggested. 
Revista Ibero-Americana de Estratégia

iberoamerican journal of Strategic Management
e-ISSN: $2176-0756$

doi.org/10.5585/riae.v20i1.17902

Received: 22 Nov. 2020 / Approved: 11 Mar. 202

Evaluation Process: Double Blind Review
C O P E

JM14473

Figure 4 - Detailed relationship between the articles of coupling and co-citation analysis

\begin{tabular}{|c|c|c|c|c|c|c|c|c|c|c|c|c|c|c|c|c|c|c|c|c|c|c|c|c|c|c|c|c|c|c|c|}
\hline \multirow{2}{*}{\multicolumn{2}{|c|}{ Bibliog }} & \multicolumn{12}{|c|}{ Factor $\mathbf{A}$} & \multicolumn{10}{|c|}{ Factor B } & \multicolumn{8}{|c|}{ Factor $\mathbf{C}$} \\
\hline & & 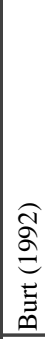 & 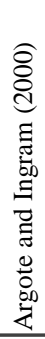 & 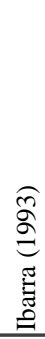 & 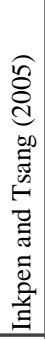 & 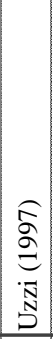 & 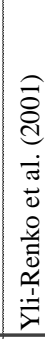 & 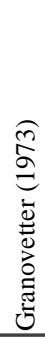 & 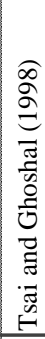 & 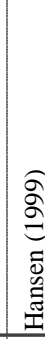 & 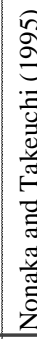 & 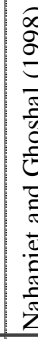 & 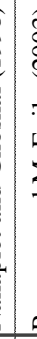 & & 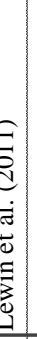 & 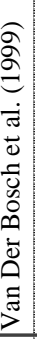 & 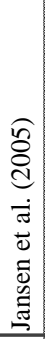 & 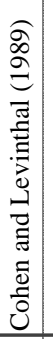 & 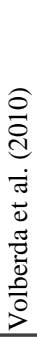 & 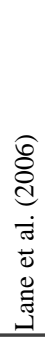 & 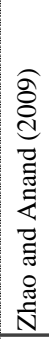 & 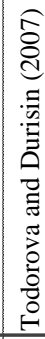 & 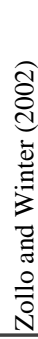 & 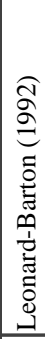 & 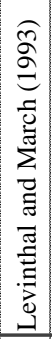 & 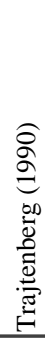 & 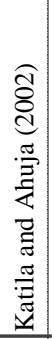 & 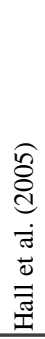 & 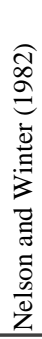 & 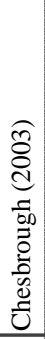 & 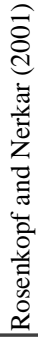 \\
\hline & Chalmers and Balan-Vnuk (2013) & & & & & & & & & & & & & & & & & & & & 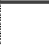 & & . & $\bullet$ & & $\bullet$ & & 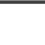 & & 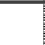 & \\
\hline & Hao and Feng (2016) & & & & & & & & & & & $\bullet$ & & & & & & & & & $\bullet$ & & $\bullet$ & & & - & - & - & & - & \\
\hline & Zhang et al. (2015b) & & & & & & & & & & & & & & & & & & & & & & & $\bullet$ & $\bullet$ & $\bullet$ & $\bullet$ & $\bullet$ & - & $\bullet$ & $\bullet$ \\
\hline 5 & Dong and Yang (2016) & & & & & & & & & & & & & & & & & & & & & & & & & & & - & & - & \\
\hline I & Chuang and Hobday (2013) & & & & & & & & & & & $\bullet$ & & & & & & & & & & & & & $\bullet$ & & & $\bullet$ & & $\bullet$ & \\
\hline & Diez-Vial and Fernandez-Olmos (2015) & & & & & & & & & & & & & & & & & & & & & & & . & & - & & $\bullet$ & - & $\bullet$ & - \\
\hline & Ojo and Raman (2016) & & & & & & & & & & & & & & & & & & & & & & & $\bullet$ & & • & - & - & & - & \\
\hline & Kaur and Mehta (2016) & & $\bullet$ & & & & & & & & & & & & & & & & & & & & & $\bullet$ & & & & & - & & \\
\hline & Wang et al. (2014c) & $\bullet$ & - & - & - & $\bullet$ & $\bullet$ & - & $\bullet$ & - & - & $\bullet$ & & & & & & & & & & & & & & & & & & & \\
\hline & Doyle et al. (2014) & $\bullet$ & $\bullet$ & & $\bullet$ & $\bullet$ & $\bullet$ & $\bullet$ & $\bullet$ & $\bullet$ & & $\bullet$ & ( & & & & & & & & & & & & & & 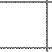 & & & & \\
\hline ฯ & Cui (2013) & $\bullet$ & & & $\bullet$ & $\bullet$ & $\bullet$ & $\bullet$ & $\bullet$ & $\bullet$ & $\bullet$ & & & & & & & & & & & & & & $\bullet$ & & $\bullet$ & & & & \\
\hline$\stackrel{8}{2}$ & Hu and Hung (2014) & & & $\bullet$ & & & & $\bullet$ & & $\bullet$ & & & ( & & & & & & & & & & & & & & & & & & \\
\hline 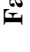 & Dominguez Gonzalez et al. (2014) & $\bullet$ & $\bullet$ & $\bullet$ & $\bullet$ & $\bullet$ & $\bullet$ & $\bullet$ & $\bullet$ & $\bullet$ & $\bullet$ & $\bullet$ & & & & & & & & & & & & & & & & & & & - \\
\hline & Perez and Gutierrez Gutierrez (2013) & $\bullet$ & $\bullet$ & $\bullet$ & & & & 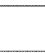 & $\bullet$ & $\bullet$ & $\bullet$ & & ( & & & & & & & & & & $\bullet$ & & & & & & & & \\
\hline & Raymond et al. (2016) & $\bullet$ & & - & & & & - & $\bullet$ & - & & - & & & & & & & & & & & & & & & & & & & \\
\hline & Ratten (2016) & & & & & & & & & & & & r & & $\bullet$ & $\bullet$ & $\bullet$ & $\bullet$ & - & - & $\bullet$ & $\bullet$ & $\bullet$ & & & & & & & & \\
\hline & Lucena (2016) & & & & & & & & & & & & & & • & & & - & - & & $\bullet$ & $\bullet$ & & & & & & & & & \\
\hline & Ahlin et al. (2014) & & & & & & & & & & $\bullet$ & & & & & - & - & & & - & & & & & & & & & & & \\
\hline$\Xi$ & Datta (2016a) & & & & & & & & & & & & & & & & $\bullet$ & & $\bullet$ & & & $\bullet$ & $\bullet$ & & & & & & & & \\
\hline 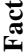 & Xie et al. (2014) & & & & & & & & & $\bullet$ & & & & & • & $\bullet$ & & $\bullet$ & $\bullet$ & $\bullet$ & $\bullet$ & $\bullet$ & & & & & & & & & \\
\hline & Lin and Chang (2015a) & & & & & & & & & & & & & & & & $\bullet$ & $\bullet$ & - & $\bullet$ & & $\bullet$ & $\bullet$ & & & & & & & & \\
\hline & Pilav-Velic and Marjanovic (2016) & & & & & & & & & $\bullet$ & & & & & & & $\bullet$ & & $\bullet$ & $\bullet$ & $\bullet$ & $\bullet$ & & & & & & & & & \\
\hline & Cozza and Zanfei (2016) & & & & & & & $\bullet$ & $\bullet$ & & $\bullet$ & 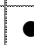 & & & • & • & $\bullet$ & & - & $\bullet$ & & $\bullet$ & & & & & & & & & • \\
\hline & Gressgard et al. (2014) & & & & & & & & & & & & & & & & & & & & & $\bullet$ & & $\bullet$ & & & & & & $\bullet$ & $\bullet$ \\
\hline$\stackrel{+}{7}$ & Lin and Chang (2015b) & & & & & & & & & & & & & & & & & & & & & $\bullet$ & & $\bullet$ & - & & - & & - & $\bullet$ & - \\
\hline 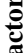 & Agarwal and $\mathrm{Wu}(2015)$ & & & & & & & & & & & & & & • & - & - & & - & - & & $\bullet$ & & & & & & & & - & \\
\hline & Martinez-Torres and Olmedilla (2016) & & & & & & $\bullet$ & & $\bullet$ & & $\bullet$ & $\bullet$ & & & & & & & $\bullet$ & $\bullet$ & & & & & & & $\bullet$ & & & $\bullet$ & \\
\hline & Spanos et al. (2015) & & & & & & & & & & & & & & & & & & & $\bullet$ & & $\bullet$ & & & $\bullet$ & & $\bullet$ & & & & $\bullet$ \\
\hline 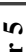 & Huang et al. (2014) & & & & & & & & & & & & & & & & & & & & & & & & & & & & & & \\
\hline & Karamanos (2016) & & & & $\bullet$ & $\bullet$ & & & & $\bullet$ & & - & & & & & & & & & & & & & & & & & & & \\
\hline 元 & Ebers and Maurer (2014) & & & & & & & & & & & & & & & & & & & & & & & & & & & & & & \\
\hline 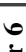 & Blind and Mangelsdorf (2016) & & & & & & & & & & & & & & & & & & & & & & & & & & & & - & & \\
\hline & Garavan et al. (2016) & & & & & & & & & & & & & & & & & & & & & & & & & & & & & & \\
\hline & Lee (2016) & & & & & & & & & & & & & & & & & $\bullet$ & - & - & & $\bullet$ & & $\bullet$ & & & - & & & - & \\
\hline
\end{tabular}

Source: Search data - Coupling and co-citation matrix.

The concept of absorptive capacity was explored, in its seminal basis, under an organizational perspective. Over time, we realized that several studies have sought to explore this topic under other levels of analysis and even from a multilevel perspective, such as, for example, Zhao and Anand (2009). Although there are still gaps that can be filled from all perspectives, we note that each of the three factors 
of intellectual structure points to the use of theoretical lenses to study absorptive capacity under specific levels of analysis.

It is highlighted that the majority of the studies that were based on Factor A (organizational network structure and knowledge transfer) were related to Factors 2 and 5, considering the organization as a unit of analysis or impact, as they address the life cycle of interorganizational alliances, the influence of the high echelon (CEO), organizational learning, and innovation of the business model. It was noticed that there is a tendency to use theories of networks, structural holes, and other theories that can help explain the phenomena that occur on the outside of the company. In this sense, there is a predominance of issues related to aspects of network formation and knowledge exchange that occur in the market, in the sector, in the cluster, or in the country.

Table 6 - Summary of the association between the results of coupling and co-citation

\begin{tabular}{|l|c|c|c|}
\hline \multicolumn{1}{|c|}{ Association between factors } & $\begin{array}{c}\text { Factor A } \\
\text { Organizational } \\
\text { network structure } \\
\text { and knowledge } \\
\text { transfer }\end{array}$ & $\begin{array}{c}\text { Factor B } \\
\text { Absorptive capacity } \\
\text { and internal and } \\
\text { external } \\
\text { organizational } \\
\text { routines }\end{array}$ & $\begin{array}{c}\text { Factor C } \\
\text { Organizational } \\
\text { learning and } \\
\text { technological } \\
\text { evolution }\end{array}$ \\
\hline $\begin{array}{l}\text { Factor 1 - Interorganizational } \\
\text { knowledge networks }\end{array}$ & $8.3 \%$ & $5.6 \%$ & $\mathbf{8 6 . 1 \%}$ \\
\hline $\begin{array}{l}\text { Factor 2 - Life cycle of alliances and } \\
\text { the influence of the upper echelon } \\
\text { (CEO) }\end{array}$ & $\mathbf{9 3 . 5 \%}$ & $1.7 \%$ & $4.8 \%$ \\
\hline $\begin{array}{l}\text { Factor 3 - Structural aspects of } \\
\text { alliances, ambidextrous innovation, and } \\
\text { entrepreneur networks }\end{array}$ & $14.8 \%$ & $\mathbf{8 3 . 3 \%}$ & $1.9 \%$ \\
\hline $\begin{array}{l}\text { Factor 4 - Technological diversification } \\
\text { and new perspectives of innovation }\end{array}$ & $12.9 \%$ & $38.7 \%$ & $\mathbf{4 8 . 4 \%}$ \\
\hline $\begin{array}{l}\text { Factor 5 - Organizational learning and } \\
\text { business model innovation }\end{array}$ & $\mathbf{1 0 0 . 0 \%}$ & $0.0 \%$ & $0.0 \%$ \\
\hline $\begin{array}{l}\text { Factor 6 - Strategic development of } \\
\text { human resources, standardization, and } \\
\text { best practices of knowledge sharing }\end{array}$ & $0.0 \%$ & $\mathbf{5 0 . 0 \%}$ & $\mathbf{5 0 . 0 \%}$ \\
\hline
\end{tabular}

Source: Search data - Coupling and co-citation matrix.

In recent years, the strategy and management literature has shown that companies invest in multiple alliances with different partners. We note that there is a tendency to better explore the aspects that involve these partnerships in order to extract better results for longer. Although there are some research fronts on this theme that try to understand what makes an alliance prone to end, such as the study of Cui (2013), it is still noticed that most studies focus on aspects related to the formation of these alliances. In general, it is clear that the different stages of the life cycle of alliances present research opportunities and their respective importance in generating results for organizations.

Decision-making related to the formation or termination of alliances may be related to the networks formed by high echelon members (CEOs and directors, for example). In addition, the relationships established between the high echelons can influence the organization's results, not only in terms of innovation but also in terms of strategic, structural, and operational levels. These relationships 
can be both formal and informal, and the impact of the relationships could be studied and eventually compared. In addition, different aspects could be explored in relation to the upper echelon members, such as their behavioral characteristics impacting the business (from decision making to strategies aimed at innovation that are adopted under their management).

Opportunities exist to break the frontiers of knowledge related to how these networks impact companies internally, in addition to considering the impact that networks formed by CEOs can bring to the external environment of the organization. This means that the networks established among high echelon members can have an impact both on the way the company presents itself to the market, as well as on how it is structured and how it generates results with the efforts of its teams and collaborators. Future studies could also explore the influence of these networks on workers and the influence of networks between workers.

The intellectual structure of Factor A is also being used to understand the implications of networks for organizational learning and innovation business models. The partnerships and networks formed between companies directly or through the upper echelon board should contribute to organizational learning, being considered one of the gains in collaborating or sharing knowledge externally. We understand that future studies can try to understand how and what aspects of networks can help organizations to generate more innovation and better performance. Another option would be to explore the effects of networks as a structure, since the business model can facilitate the transfer and absorption of knowledge between those involved.

Factor B (absorptive capacity and internal and external organizational routines) was related to Factors 3 and 6, dealing with topics such as the mode of interaction of companies, the geographical scope of alliances, networks of entrepreneurs, strategic development of human resources, standardization and best practices of knowledge sharing. Although Factor B also addressed themes at organizational levels, it is perceived that there are studies at the collective level. It is also noticed that there is a tendency to use small and medium-sized companies and entrepreneurs as a unit of analysis in addition to large organizations.

We observed that the study trends suggested, based on the intellectual structure of Factor B, are linked to the activities carried out by organizations or entrepreneurs to share knowledge and structural aspects that make this exchange feasible. For example, the modes of interaction, geographic scope, and ambidexterity are some characteristics analyzed in networks as strategies to generate sources of exploration and exploitation for firms. We understand that absorptive capacity and organizational routines can play an important role in generating innovative solutions and these structural aspects of networks can help companies to diversify their portfolios.

Even with technological advances, it is clear that processes and people continue to be an important part of the exchange and transformation of knowledge to reflect in the results of organizations. Therefore, standardization of processes and best practices become crucial themes for organizations to achieve their goals, which can be solving technical problems, knowledge seeking, influencing 
regulation, and facilitating market access. A strategic look at human capital is also evident from the use of theories that aid understanding of the importance of people to the results of organizations, such as the resource-based view and dynamic capabilities.

Finally, Factor C (organizational learning and technological evolution) was related to Factors 1 and 4, presenting aspects related to the types of interorganizational knowledge networks, technological diversification, and new perspectives of innovation, besides a different look at Factor 6. The intellectual structure that supports these study trends aims at understanding the impact of knowledge exchanges for the company internally. In this sense, we realize that there is a look at innovation from some specific perspectives, such as through patents, open innovation, and technology parks. For example, Zhang et al. (2015) make it clear that the relationship between open innovation and firm performance has been explored in the literature, but they also reinforce in their study that the results are controversial. Thus, there are opportunities to explore the effects of absorptive capacity in relation to these strategies for generating innovation.

The adoption of different innovation strategies means that companies have different sources of knowledge to generate new products and services for their customers. Therefore, the trends recommended by these factors reinforce the importance of processes and people so that the exchange of knowledge becomes a result. The organizational learning literature ends up being highlighted with theories that help explain this internalization of knowledge and the use of this information so that organizations can reinvent themselves and be able to remain competitive from the internal intellectual capital.

After analyzing the association between the factors that emerged from the cocitation and pairing analyses, we realized that the results found could contribute to the development of new studies that address existing gaps based on the absorptive capacity model of Zahra and George (2002). The authors identified key dimensions of absorptive capacity, proposed the reconceptualization of this construct and also presented a model that connects the antecedents, moderators, and outcomes of absorptive capacity (Figure 5). We understand that the findings proposed in this bibliometric study can address the avenues needed to advance knowledge in each dimension of the model proposed by Zahra and George (2002). 
Figure 5 - Model of Absorptive Capacity

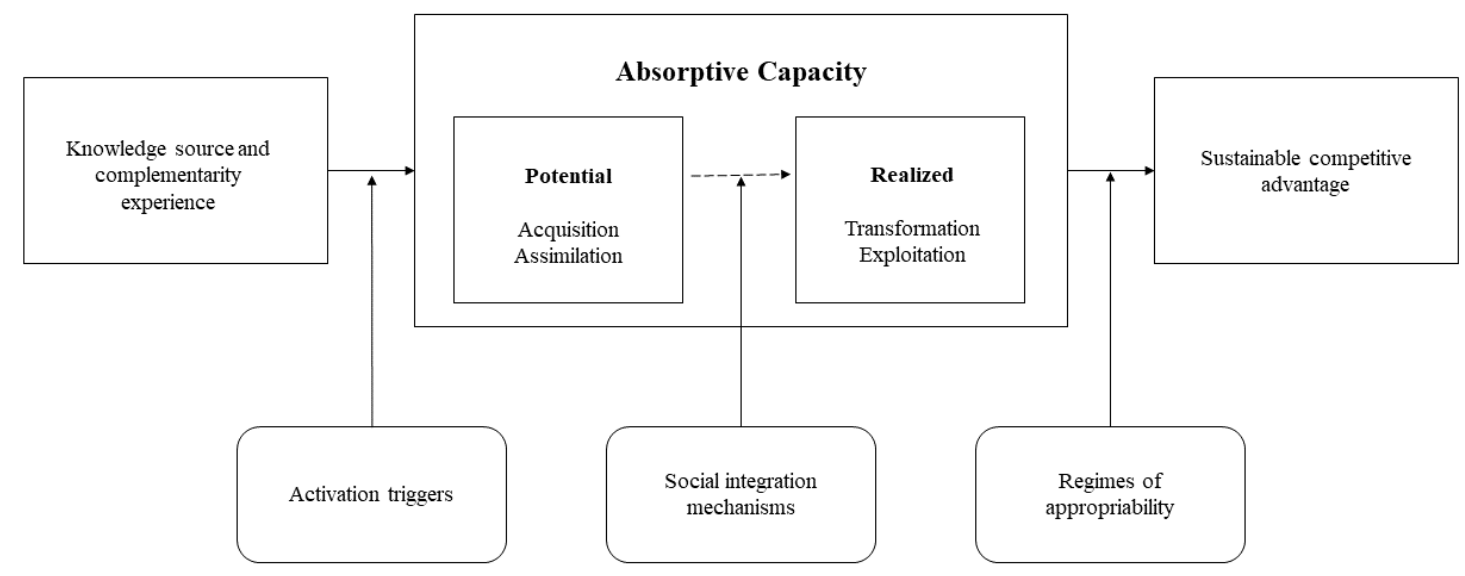

Source: Zahra and George (2002).

We developed a theoretical model (Figure 6) that can summarize the findings generated in the association of factors and to highlight the insights that emerge from these relationships. This model also expressed how our findings can contribute to the Zahra and George model. The factors related to the suggestions for future studies that came from the coupling analysis were made available in the same columns as their intellectual structures identified through the co-citation analysis. The exception is Factor 4, which presents an intellectual structure divided equally between the theoretical fronts presented in factors B and C. We realized that some subjects are related, although they appeared in different mainstream research factors and intellectual structures. These themes are connected with a dashed line, since they are insights that were not directly pointed out by the results of factor analysis. Other researchers can assess in more depth the gaps that may arise from looking at these themes from the perspective of theories, which could complement the understanding in different perspectives. 
Figure 6 - Theoretical model summarizing the study's findings

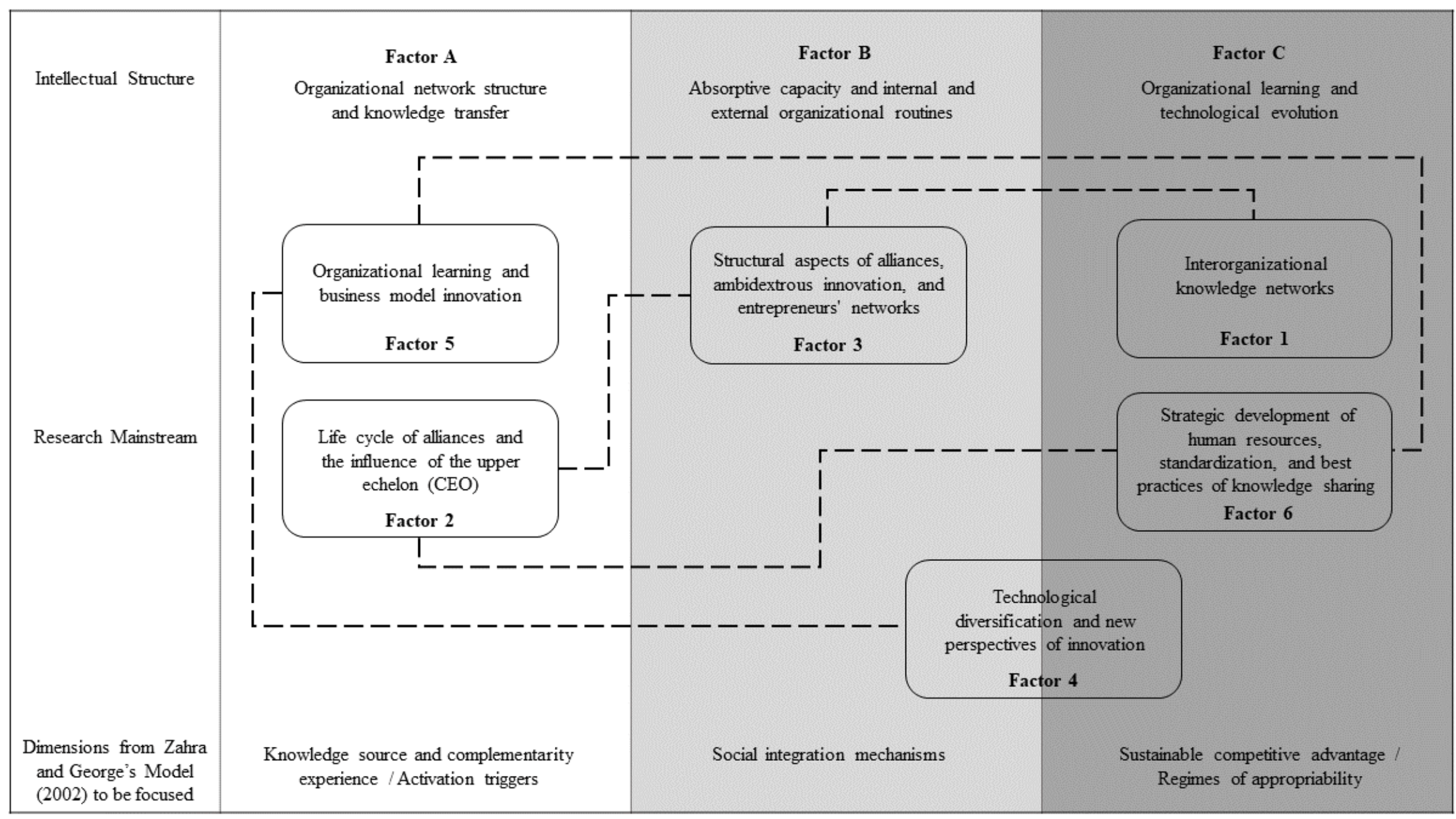

Source: Elaborated by the authors. 
We realized that the intellectual structure presented in Factor A (organizational network structure and knowledge transfer) is connected with the knowledge source and complementarity experience and activation triggers proposed by Zahra and George (2002) as antecedents of absorptive capacity. Zahra and George (2002) suggest that external sources of knowledge can significantly influence the potential absorptive capacity of organizations. In addition, activation triggers are considered as events that can moderate the impact of knowledge sources and experience on potential absorptive capacity development (Zahra \& George, 2002). In this way, it seems that the trends of future studies linked to this theoretical basis appear as ways to contribute to research gaps focused on the stages of knowledge acquisition and assimilation.

Zahra and George (2002) also suggested that social integration mechanisms are important to facilitate knowledge sharing and exploitation. The intellectual structure identified by means of Factor B (absorptive capacity and internal and external organizational routines) seems to propose the adequate theoretical basis to explore the research gaps that still exist in this regard. Studies carried out from the trends connected with this theoretical basis could contribute to the reduction in the gap between the potential absorptive capacity and the realized absorptive capacity.

In addition, we identified that Factor $\mathrm{C}$ (organizational learning and technological evolution) seems to match the proposal of Zahra and George (2002) when talking about sustainable competitive advantage and regimes of appropriability. The themes that emerged as a suggestion for future studies based on the intellectual structure of factor $\mathrm{C}$ may contribute to the research gaps on realized absorptive capacity. Thus, it would be possible to contribute to the literature related to the transformation and exploitation capabilities to convert knowledge into new products and services, enhancing performance and yielding a competitive advantage through a strategic look at the organization's internal intellectual capital. Furthermore, we observe that studies found in Factor C could help to explore or explain the institutional and industry dynamics that affect the firm's ability to protect and benefit from the advantages of new products or processes, phenomena called regimes of appropriability by Zahra and George (2002).

\section{Final considerations}

Due to the increasing volume of publications involving absorptive capacity and innovation, an overview of accumulated knowledge is useful to give meaning to what is already known in the scientific field and generate a new research agenda. For this reason, we analyze the scientific production related to the absorptive capacity and innovation, presenting the trends of future studies through the coupling analysis and the recommended intellectual structure to study these themes through the co-citation analysis. We also present network diagrams to demonstrate how the studies are related.

The six factors from the coupling analysis were: interorganizational knowledge networks; the life cycle of alliances and the influence of the upper echelon (CEO); structural aspects of alliances, 
ambidextrous innovation, and entrepreneur networks; technological diversification and new perspectives of innovation; organizational learning and business model innovation; and strategic development of human resources, standardization and best practices of knowledge sharing. The three factors from the co-citation analysis were: organizational network structure and knowledge transfer; absorptive capacity and internal and external organizational routines; and organizational learning and technological evolution.

This article identified how absorptive capacity and organizational learning are interconnected through the literature of new perspectives of innovation and of technological diversification. Apparently, absorptive capacity is the general term that generically defines how the organization learns and organizational learning can be thought of as the various specificities that may be involved in the way the organization learns. We are arguing that literature on new perspectives on innovation could bring more specific learning concepts and would depend on developing details of the macro phases of absorptive capacity. This partial overlap between absorptive capacity and organizational learning is a possible theoretical contribution of this bibliometric study. What before could be understood as a synonym, does not seem to be sustained in light of the arguments presented herein. If we consider this view of intersection or partial overlap, we can rethink the ways of using the logic of absorptive capacity as a general concept and organizational learning as a possible evolution of the concept, due to dedicating ourselves to understanding the new perspectives of innovation, which will depend on derivations and developments of the more general concepts.

In terms of contribution to practice, by treating organizational learning as the set of theories that detail specialized or special learning processes, we have created a reduction in the level of abstraction. It would be possible, for example, to build certain frameworks with greater security and precision from the observation of an innovation phenomenon and to identify the presence or absence of learning components, which is not simple at the high level of abstraction that is absorptive capacity.

As a methodological contribution, we were able to present paths for future studies that could expand the frontiers of knowledge on what is known today about absorptive capacity, considering the combination of two bibliometrics techniques. We associated the results of these analyses and summarized the findings in the form of a theoretical model that is connected to the seminal model of absorptive capacity. The way in which we associate the results of all the analyses carried out in this study can be considered as a methodological contribution, combining the methodological procedures suggested by the protocols of Quevedo-Silva et al. (2016) and Serra et al. (2018, 2019). In addition to these contributions, we were able to indicate the themes to be explored in new research with the recommendation of an adequate theoretical basis to fill the gaps related to each part of the model proposed by Zahra and George (2002).

This study has some limitations, and there are opportunities for improvement in its development. There is also openness for future studies to complement this research with new content analyses or through conduction of an in-depth review of the publications identified in the factors of co-citation, 
coupling, and network analysis. The choice of databases (Scopus and Web of Science) covers a large volume of journals and articles; however, it is known that these databases do not contain one hundred percent of publications on this topic. Other researchers could make use of other databases to perform further analyses. Future studies may explore each of the factors found explicitly through systematic reviews of the literature or other methods to understand better each of the themes found.

\section{References}

Agarwal, J., \& Wu, T. (2015). Factors Influencing Growth Potential of E-Commerce in Emerging Economies: An Institution-Based N-OLI Framework and Research Propositions. Thunderbird International Business Review, 57(3), 197-215. https://doi.org/10.1002/tie.21694.

Ahlin, B., Drnovšek, M., \& Hisrich, R. D. (2014). Exploring the moderating effects of absorptive capacity on the relationship between social networks and innovation. Journal of East European Management Studies, 19(2), 213-235. https://doi.org/10.1688/JEEMS-2014-02-Ahlin.

Argote, L., \& Ingram, P. (2000). Knowledge transfer: A basis for competitive advantage in firms. Organizational behavior and human decision processes, 82(1), 150-169.

Albort-Morant, G., Leal-Rodríguez, A. L., \& De Marchi, V. (2018). Absorptive capacity and relationship learning mechanisms as complementary drivers of green innovation performance. Journal of Knowledge Management, 22(2), 432-452. https://doi.org/10.1108/JKM-07-2017-0310.

Blind, K., \& Mangelsdorf, A. (2016). Motives to standardize: Empirical evidence from Germany. Technovation, 48-49, 13-24. https://doi.org/10.1016/j.technovation.2016.01.001.

Burt, R. S. (1992). Structural holes: The social structure of competition. Harvard University Press.

Chalmers, D. M., \& Balan-Vnuk, E. (2013). Innovating not-for-profit social ventures: Exploring the microfoundations of internal and external absorptive capacity routines. International Small Business Journal, 31(7), 785-810.

Chesbrough, H. W. (2003). Open innovation: The new imperative for creating and profiting from technology. Harvard Business Press.

Chuang, Y. S., \& Hobday, M. (2013). Technological upgrading in Taiwan's TFT-LCD industry: Signs of a deeper absorptive capacity? Technology Analysis and Strategic Management, 25(9), 10451066. https://doi.org/10.1080/09537325.2013.832748.

Cohen, W. M., \& Levinthal, D. A. (1990). Absorptive Capacity : A New Perspective on and Innovation Learning. Administrative Science Quarterly, 35(1), 128-152.

Cozza, C., \& Zanfei, A. (2016). Firm heterogeneity, absorptive capacity and technical linkages with external parties in Italy. Journal of Technology Transfer, 41(4), 872-890. https://doi.org/10.1007/s10961-015-9404-0.

Cui, A. S. (2013). Portfolio dynamics and alliance termination: The contingent role of resource dissimilarity. Journal of Marketing, 77(3), 15-32. https://doi.org/10.1509/jm.11.0164.

Datta, A. (2016). Antecedents to radical innovations: a longitudinal look at firms in the information technology industry by aggregation of patents. International Journal of Innovation Management, 20(7), 1-31. https://doi.org/10.1142/S1363919616500687. 
Díez-Vial, I., \& Fernández-Olmos, M. (2015). Knowledge spillovers in science and technology parks: how can firms benefit most? Journal of Technology Transfer, 40(1), 70-84. https://doi.org/10.1007/s10961-013-9329-4.

Dominguez Gonzalez, R. V. D., Martins, M. F., \& Toledo, J. C. (2014). Managing knowledge in a service provider: A network structure-based model. Journal of Knowledge Management, 18(3), 611-630. https://doi.org/10.1108/JKM-12-2013-0502.

Dong, J. Q., \& Yang, C. H. (2016). Being central is a double-edged sword: Knowledge network centrality and new product development in U.S. pharmaceutical industry. Technological Forecasting and Social Change, 113, 379-385. https://doi.org/10.1016/j.techfore.2016.07.011.

Doyle, E., McGovern, D., \& McCarthy, S. (2014). Compliance-innovation: integrating quality and compliance knowledge and practice. Total Quality Management \& Business Excellence, 25(9-10), 1156-1170.

Ebers, M., \& Maurer, I. (2014). Connections count: How relational embeddedness and relational empowerment foster absorptive capacity. Research Policy, 43(2), 318-332. https://doi.org/10.1016/j.respol.2013.10.017.

Fernandez Pérez, V., \& Gutiérrez Gutiérrez, L. (2013). External managerial networks, strategic flexibility and organisational learning: A comparative study among non-QM, ISO and TQM firms. Total Quality Management and Business Excellence, 24(3-4), 243-258. https://doi.org/10.1080/14783363.2012.669558.

Garavan, T., Shanahan, V., Carbery, R., \& Watson, S. (2016). Strategic human resource development: Towards a conceptual framework to understand its contribution to dynamic capabilities. Human Resource Development International, 19(4), 289-306. https://doi.org/10.1080/13678868.2016.1169765.

Granovetter, M. S. (1973). The strength of weak ties. American journal of sociology, 78(6), 13601380 .

Gressgård, L. J., Amundsen, O., Aasen, T. M., \& Hansen, K. (2014). Use of information and communication technology to support employee-driven innovation in organizations: A knowledge management perspective. Journal of Knowledge Management, 18(4), 633-650. https://doi.org/10.1108/JKM-01-2014-0013.

Hair, J. F., Black, W. C., Babin, B. J., Anderson, R. E., \& Tatham, R. L. (2009). Análise multivariada de dados.

Hall, B. H., Jaffe, A., \& Trajtenberg, M. (2005). Market value and patent citations. Rand Journal of Economics, 16-38.

Hao, B., \& Feng, Y. (2016). How networks influence radical innovation: the effects of heterogeneity of network ties and crowding out. Journal of Business and Industrial Marketing, 31(6), 758-770. https://doi.org/10.1108/JBIM-09-2012-0165.

Hu, M. C., \& Hung, S. C. (2014). Taiwan's pharmaceuticals: A failure of the sectoral system of innovation? Technological Forecasting and Social Change, 88, 162-176. https://doi.org/10.1016/j.techfore.2014.06.021.

Huang, H. C., Lai, M. C., Kao, M. C., \& Sung, C. H. (2014). A team-learning framework for business model innovation in an emerging market. Journal of Management and Organization, 20(1), 100120. https://doi.org/10.1017/jmo.2014.20. 
Ibarra, H. (1993). Network centrality, power, and innovation involvement: Determinants of technical and administrative roles. Academy of Management journal, 36(3), 471-501.

Inkpen, A. C., \& Tsang, E. W. K. (2005). Social capital networks, and knowledge transfer. Academy of Management Review, 30(1), 146-165. https://doi.org/10.5465/AMR.2005.15281445.

Jansen, J. J. P., Van Den Bosch, F. A. J., \& Volberda, H. W. (2005). Managing potential and realized absorptive capacity: How do organizational antecedents matter? Academy of Management Journal, 48(6), 999-1015. https://doi.org/10.5465/AMJ.2005.19573106.

Karamanos, A. G. (2016). Effects of a firm's and their partners' alliance ego-network structure on its innovation output in an era of ferment. $R$ and D Management, 46, 261-276. https://doi.org/10.1111/radm.12163.

Katila, R., \& Gautam, A. (2002). Something Old, Something New: A Longitudinal Study of Search Behavior and New Product Introduction. The Academy of Management Annals, 45(6), 1183-1194.

Kaur, V., \& Mehta, V. (2016). Leveraging Knowledge Processes for Building Higher-Order Dynamic Capabilities An Empirical Evidence from It Sector in India . JIMS8M: The Journal of Indian Management \& Strategy, 21(3), 37. https://doi.org/10.5958/0973-9343.2016.00023.5.

Lane, P. J., Koka, B. R., \& Pathak, S. (2006). The reification of absorptive capacity: A critical review and rejuvenation of the construct. Academy of management review, 31(4), 833-863.

Lee, M. C. (2016). Knowledge management and innovation management: Best practices in knowledge sharing and knowledge value chain. International Journal of Innovation and Learning, 19(2), 206226. https://doi.org/10.1504/IJIL.2016.074475.

Leonard-Barton, D. (1992). Core capabilities and core rigities: a paradox in managing new product development. Strategic Management Journal, 13, 111-125. https://doi.org/10.2307/2486355.

Levine, S. S., \& Kurzban, R. (2006). Explaining clustering in social networks: Towards an evolutionary theory of cascading benefits. Managerial and Decision Economics, 27(2-3), 173-187.

Levinthal, D. A., \& March, J. G. (1993). The myopia of learning. Strategic management journal, 14(S2), 95-112.

Lewin, A. Y., Massini, S., \& Peeters, C. (2011). Microfoundations of internal and external absorptive capacity routines. Organization Science, 22(1), 81-98. https://doi.org/10.1287/orsc.1100.0525.

Limaj, E., \& Bernroider, E. W. N. (2017). The roles of absorptive capacity and cultural balance for exploratory and exploitative innovation in SMEs. Journal of Business Research, (September 2016), 0-1. https://doi.org/10.1016/j.jbusres.2017.10.052.

Lin, C., \& Chang, C. C. (2015a). A patent-based study of the relationships among technological portfolio, ambidextrous innovation, and firm performance. Technology Analysis and Strategic Management, 27(10), 1193-1211. https://doi.org/10.1080/09537325.2015.1061119.

Lin, C., \& Chang, C. C. (2015b). The effect of technological diversification on organizational performance: An empirical study of S\&P 500 manufacturing firms. Technological Forecasting and Social Change, 90(PB), 575-586. https://doi.org/10.1016/j.techfore.2014.02.014.

Liu, C., \& Gui, Q. (2016). Mapping intellectual structures and dynamics of transport geography research: a scientometric overview from 1982 to 2014. Scientometrics, 109(1), 159-184.

https://doi.org/10.1007/s11192-016-2045-8. 
Lucena, A. (2016). The interaction mode and geographic scope of firms' technology alliances: implications of balancing exploration and exploitation in R\&D. Industry and Innovation, 23(7), 595-624. https://doi.org/10.1080/13662716.2016.1201648.

Martinez-Torres, R., \& Olmedilla, M. (2016). Identification of innovation solvers in open innovation communities using swarm intelligence. Technological Forecasting and Social Change, 109, 15-24. https://doi.org/10.1016/j.techfore.2016.05.007.

Nahapiet, J., \& Ghoshal, S. (1998). Social capital, intellectual capital, and the organizational advantage. Academy of management review, 23(2), 242-266.

Nelson, R. R.; Winter, S. G. (1982). An evolutionary theory of economic change. harvard university press.

Nonaka, I., \& Takeuchi, H. (1995). The knowledge-creating company: How Japanese companies create the dynamics of innovation. Oxford university press.

Ojo, A. O., \& Raman, M. (2016). Antecedents of local personnel absorptive capacity in joint project engineering teams in Nigeria. International Journal of Knowledge Management, 12(2), 38-53. https://doi.org/10.4018/IJKM.2016040103.

Okubo, Y. (1997). Bibliometric Indicators and Analysis of Research Systems: Methods and Examples. OECD Science, Technology and Industry Working Papers, 1(1997/01). https://doi.org/https://doi.org/10.1787/208277770603.

Pilav-Velić, A., \& Marjanovic, O. (2016). Integrating open innovation and business process innovation: Insights from a large-scale study on a transition economy. Information and Management, 53(3), 398-408. https://doi.org/10.1016/j.im.2015.12.004.

Quevedo-Silva, F., Santos, E. B., Brandão, M. M., \& Vils, L. (2016). Estudo Bibliométrico: Orientações sobre sua Aplicação. Revista Brasileira de Marketing, 15(02), 246-262. https://doi.org/10.5585/remark.v15i2.3274.

Ratten, V. (2016). Sport innovation management: towards a research agenda. Innovation: Management, Policy and Practice, 18(3), 238-250. https://doi.org/10.1080/14479338.2016.1244471.

Raymond, L., Bergeron, F., Croteau, A.-M., \& St-Pierre, J. (2016). IT-enabled Knowledge Management for the Competitive Performance of Manufacturing SMEs: An Absorptive Capacitybased View. Knowledge and Process Management, 23(2), 110-123. https://doi.org/10.1002/kpm.1503.

Reagans, R., \& McEvily, B. (2003). Network structure and knowledge transfer: The effects of cohesion and range. Administrative science quarterly, 48(2), 240-267.

Rosenkopf, L., \& Nerkar, A. (2001). Beyond local search: boundary-spanning, exploration, and impact in the optical disk industry. Strategic management journal, 22(4), 287-306.

Rossetto, D. E., Carvalho, F. C. A. de, Bernardes, R. C., \& Borini, F. M. (2017). Absorptive Capacity and Innovation: An Overview of International Scientific Production of Last Twenty-Five Years. International Journal of Innovation, 5(1), 97-113.

Schweisfurth, T. G., \& Raasch, C. (2018). Absorptive capacity for need knowledge: Antecedents and effects for employee innovativeness. Research Policy, (January).

https://doi.org/10.1016/j.respol.2018.01.017. 
Seguí-Mas, E., Signes-Pérez, E., Sarrión-Viñes, F., \& Alegre Vidal, J. (2016). Bibliometric analysis of the international literature on open innovation and absorptive capacity. Intangible Capital, 12(1), 51-72. doi: http://dx.doi.org/10.3926/ic.685.

Serra, R. A. F., Cirani, C. B. S., \& Moutinho, J. A. (2019). "Dicas" e Orientações para Complemento do Procedimento sobre Estudos Bibliométricos de Co-Citação e Paremento Bibliográfico. Iberoamerican Journal of Strategic Management, 18(3), 1-8.

Serra, R. A. F., Ferreira, M. P., Guerrazzi, L. A. C., \& Scaciotta, V. (2018). Doing Bibliometric Reviews for the Iberoamerican Journal of Strategic Management, (September), 0-16. https://doi.org/10.5585/ijsm.v17i3.2713.

Spanos, Y. E., Vonortas, N. S., \& Voudouris, I. (2015). Antecedents of innovation impacts in publicly funded collaborative R\&D projects. Technovation, 36, 53-64. https://doi.org/10.1016/j.technovation.2014.07.010.

Todorova, G., \& Durisin, B. (2007). Absorptive capacity: Valuing a reconceptualization. Academy of management review, 32(3), 774-786.

Trajtenberg, M. (1990). A Penny for Your Quotes: Patent Citations and the Value of Innovations. The RAND Journal of Economics, 21(1), 172. https://doi.org/10.2307/2555502.

Tsai, W., \& Ghoshal, S. (1998). Social capital and value creation: The role of intrafirm networks. Academy of management Journal, 41(4), 464-476.

Uzzi, B. (1997). Social structure and competition in interfirm networks: The paradox of embeddedness. Administrative science quarterly, 35-67.

Van den Bosch, F. A., Volberda, H. W., \& De Boer, M. (1999). Coevolution of firm absorptive capacity and knowledge environment: Organizational forms and combinative capabilities. Organization science, 10(5), 551-568.

Vogel, R., \& Güttel, W. H. (2013). The dynamic capability view in strategic management: A bibliometric review. International Journal of Management Reviews, 15(4), 426-446. https://doi.org/10.1111/ijmr.12000.

Volberda, H. W., Foss, N. J., Lyles, M. A., \& Foss, N. J. (2016). Absorbing the Concept of Absorptive Capacity: How to Realize Its Potential in the Organization Field. Organization Science, 21(4), 931951.

Wang, C., Rodan, S., Fruin, M., \& Xu, X. (2014). Knowledge networks, collaboration networks, and exploratory innovation. Academy of Management Journal, 57(2), 484-514.

Xie, X., Zou, H., \& Qi, G. (2018). Knowledge absorptive capacity and innovation performance in high-tech companies: A multi-mediating analysis. Journal of Business Research, 88(June 2017), 289-297. https://doi.org/10.1016/j.jbusres.2018.01.019.

Xie, Y., Liu, H., \& Gao, S. (2014). Innovation generation and appropriation: The dual roles of political ties in Chinese firms' new product development. International Journal of Technology Management, 65(1-4), 215-239. https://doi.org/10.1504/IJTM.2014.060958.

Yli-Renko, H., Autio, E., \& Sapienza, H. J. (2001). Social capital, knowledge acquisition, and knowledge exploitation in young technology-based firms. Strategic Management Journal, 22(6-7), 587-613. https://doi.org/10.1002/smj.183. 
Zahra, S. A., \& George, G. (2002). Absorptive Capacity: A Review, Reconceptualization, and Extension. Academy of Management Review, 27(2), 185-203.

https://doi.org/10.5465/amr.2002.6587995.

Zhang, M., Zhao, X., Lyles, M. A., \& Guo, H. (2015). Absorptive capacity and mass customization capability. International Journal of Operations \& Production Management, 35(9), 1275-1294. https://doi.org/10.1108/IJOPM-03-2015-0120.

Zhao, Z. J., \& Anand, J. (2009). A multilevel perspective on knowledge transfer: evidence from the Chinese automotive industry. Strategic management journal, 30(9), 959-983.

Zollo, M., \& Winter, S. G. (2002). Deliberate learning and the evolution of dynamic capabilities. Organization science, 13(3), 339-351.

Zupic, I., \& Čater, T. (2015). Bibliometric Methods in Management and Organization. Organizational Research Methods, 18(3), 429-472. https://doi.org/10.1177/1094428114562629. 